\title{
LA PROSTITUCIÓN EN ESPAÑA: EL LIMBO DE LA ALEGALIDAD
}

\author{
Elena Boza Moreno ${ }^{1}$
}

Resumen: El fenómeno de la prostitución es abordado desde diferentes perspectivas de la política criminal, sin embargo, en España el tratamiento que recibe el ejercicio de la prostitución, por personas mayores de edad y que prestan su consentimiento, dista mucho del de otros países que adoptan políticas abolicionistas o prohibicionistas. En este estudio, se muestra la realidad por la que atraviesa este sector, un vacío legal, que lo estigmatiza aún más. Si bien la explotación sexual de un tercero o el lucro proveniente del desempeño de este oficio por otra persona, está penado y perseguido, el libre ejercicio no está regulado a nivel estatal, quedando así en manos de los municipios su regulación a través de ordenanzas municipales que no hacen más que agravar la difícil situación que viven aquellas personas que ejercen la prostitución. Palabras claves: prostitución, alegalidad, prohibicionismo, ordenanzas municipales, estigmatización.

Recibido: noviemre 2018. Aceptado: junio 2019

1 Profesora de Derecho Penal y Criminología. ORCID ID: 0000-0003-0133-6801. Área Departamental de Derecho del Centro Universitario San Isidoro adscrito a la Universidad Pablo de Olavide de Sevilla. Dirección Calle Leonardo Da Vinci, 17-B. E-mail: m-lenab@hotmail.com 


\begin{abstract}
The phenomenon of prostitution is approached from different perspectives of criminal policy, however, in Spain the treatment received by the exercise of prostitution, by people of legal age and who give their consent, is far from that of other countries that adopt policies abolitionists or prohibitionists. In this study, the reality that this sector goes through is shown, a legal vacuum that stigmatizes it even more. Although the sexual exploitation of a third party or the profit from the performance of this office by another person, is punishable and persecuted, the free exercise is not regulated at the state level, thus being in the hands of the municipalities its regulation through municipal ordinances that only aggravate the difficult situation of those who practice prostitution.
\end{abstract}

Keywords: prostitution, alegality, prohibition, municipal ordinances, stigmatization.

\title{
I. Consideraciones previas
}

En torno al mundo de la prostitución han surgido diferentes posturas a lo largo de la historia. La problemática que dicho tema supone, implica una serie de debates respecto de si debe ser regulada como trabajo sexual, prohibida y penalizando su ejercicio, o abolida del sistema, es decir, actualmente existen varios modelos ideológicos de cómo entender este fenómeno y que de algún modo suponen un determinado control del ejercicio de la prostitución.

Aunque no siempre coinciden las categorías utilizadas por unos y otros autores, las más utilizadas son cuatro, el reglamentarismo, el abolicionismo, el prohibicionismo y el modelo laboral o legalizador.

Las bases de cada uno de estos modelos se encuentran en diversos enfoques ideológicos, de modo que desde la moral tradicional, enfoque asociado con los sectores sociales más conservadores, mantienen un sistema de creencias y actitudes en base al cual se divide a las mujeres en dos grandes sectores, las "buenas", "decentes", las esposas y madres que respetan el 
orden establecido y las "malas", "perversas" y "degeneradas". Las primeras son normales, las segundas son estigmatizadas y no pueden ser presentadas en sociedad. Proponen seguir manteniendo la prostitución en la marginalidad, o invisibilizándola en locales fuera de los centros de las ciudades, teniendo el control unos pocos, y presentándola socialmente como una actividad estigmatizada que practican las mujeres voluntariamente. Enfoque que se corresponde con la ideología reglamentarista, que podemos encontrar en países como Colombia.

En líneas similares, otro sector, reconoce en esta práctica una actividad indigna, hasta el punto de que quien la desarrolla debe ser considerado como un delincuente y por consiguiente perseguido y sancionado penalmente. Partiendo de esta idea se busca su prohibición bajo castigo.

Por otro lado, desde la crítica progresista a esta moral tradicional, denuncian la estigmatización con la que han marcado a las prostitutas y la hipocresía que encierra su rechazo social. Critican la doble moral que existe al respecto y el puritanismo con el que tratan todo lo referido a las relaciones sexuales y por eso se esfuerzan en demostrar que la prostitución no es algo pecaminoso, ni perverso. Defienden la prostitución alegando que es una cuestión de libertad sexual y su objetivo principal es normalizarla ${ }^{2}$ y reconocerla como un trabajo, tal y como mantiene el modelo legalizador.

También puede ser entendida desde una perspectiva de género, según la cual, este fenómeno supone una práctica llevada a cabo mayormente por mujeres, y supone una situación de explotación por parte del hombre, así como un claro ejemplo de violencia de género, ante el cual, quien ejerce esta actividad es víctima y debe ser entendida como tal, necesitando protección frente al abuso y la explotación, es por ello que desde esta postura se persigue la eliminación de esta práctica por ser contraria

2 Véase al respecto, MARTÍN TORPEDO, Prostitución organizada: género, raza, clase y globalización de la explotación, 2006, pp. 13-14. 
a los derechos fundamentales y la libertad de este sector, tal y como se defiende desde la postura abolicionista.

En definitiva, podemos deducir a grandes rasgos una tendencia a demonizar esta actividad, frente a un reconocimiento de la misma como una actividad propia de beneficios y protección. Es por ello que se afirma que tanto el modelo legalizador, como el modelo abolicionista han resultado ser los sistemas más aceptados y desplegados por la política criminal de los diferentes países, internacionales y europeos, no obstante y como apuntábamos al principio, junto a estos dos modelos, coexisten aquellos otros, que aunque también pueden observarse en distintas legislaciones, no han tenido la misma aceptación o la misma repercusión, más no resultan indiferentes para los estudiosos de este tema.

Junto a los sistemas que como hemos visto criminalizan la prostitución y cualquier práctica relacionada con la misma, como son los sistemas prohibicionistas o abolicionistas, y los otros sistemas que la controlan en cierto modo, bien ejerciendo represión y una mayor estigmatización, como es el caso del reglamentarismo, bien reconociendo derechos y obligaciones a las prostitutas, convive un quinto escenario, que si bien no establece un régimen determinado sobre este tema, puede ser entendida como una forma de politizar, aunque formalmente en realidad no se trate de un sistema como tal, pues no responde a las características propias de un sistema ideológico ${ }^{3}$.

En España el ejercicio de la prostitución, no es constitutivo de delito. Ni siquiera se considera ilegal, por lo que puede concluirse que cuanto menos formalmente, el sistema que rige

3 Para algunos autores se trata de cuatro modelos de tratamiento normativo en lugar de cinco, puesto que la situación que se vive en España, es más una ausencia de control que un modelo en sí mismo. Al respecto véanse, MAQUEDA ABREU, Prostitución, feminismos y Derecho penal, 2009, pp. 13 y ss.; WIJERS, M., en OSBORNE (ed.), Trabajador@s del sexo: derechos, migraciones y tráfico en el $S$. XXI, 2004, pp. 210 y ss.; CARMONA CUENCA, en SERRA CRISTÓBAL (coord.), Prostitución y trata: marco jurídico y régimen de derechos, 2007, pp.50 y ss. 
en nuestro país, no es un modelo prohibicionista. No siendo ilegal, tampoco se regula la forma en que esta actividad debe desempeñarse cuando es ejercida voluntariamente, por lo que puede afirmarse que el ejercicio de esta actividad en nuestro país se encuentra en lo que podríamos denominar como limbo jurídico ${ }^{4}$.

No existe una clara política abolicionista con respecto a esta materia, del mismo modo que tampoco es característica una política regulacionista o una legalización de la actividad. Estamos pues, ante una situación de ausencia de regulación, que se produce en varios países, como por ejemplo Argentina o Brasil. En estos la prostitución ejercida de forma libre y voluntaria no está ni permitida, ni prohibida, ni mucho menos castigada, no obstante en relación con la prostitución forzosa sí se prevén sanciones y una persecución jurídico-penal ${ }^{5}$.

Las personas que ejercen la prostitución en nuestro país se enfrentan a una situación de alegalidad e incertidumbre. En una calle pueden ser multadas y si cruzan a otra calle, en otro municipio a lo mejor no lo son. Tampoco se encuentran en la misma situación si están en Cataluña en lugar de Extremadura, $o$ en una carretera estatal en lugar de una autonómica, etc. No obstante el proxenetismo sí es un delito recogido en el $\mathrm{Cp}^{6}$.

4 Véase al respecto, VILLACAMPA ESTIARTE, RDPC, 2012, p. 129.

5 Así por ejemplo, QUINTERO OLIVARES, destaca que “....España “parece" optar por la de un impreciso abolicionismo, que consiste, como primera medida, en no legalizarla pero tampoco criminalizarla, dejando la cuestión en una insoportable indefinición; la prostitución, de acuerdo con esa extraña contemplación legal no es lícita ni ilícita. Las consecuencias se plasman en hechos ya sabidos, y así no será delictivo, ni ilícito, ejercer la prostitución, pero tampoco la persona prostituida podrá aspirar a que su trabajo sea reconocido como legítimo y de acuerdo con ese reconocimiento pueda aspirar al régimen de la sanidad pública, por ejemplo, mediante la correspondiente cotización como trabajador, ni tampoco a obtener la debida protección del derecho si sus servicios no son remunerados de acuerdo con lo pactado", en VILLACAMPA ESTIARTE (coord.), Prostitución: ¿hacia la legalización?, 2012, p. 159.

6 Sobre los delitos relativos a la prostitución véase, GARCÍA ÁLVAREZ, en La reforma del Código penal a debate, Cuadernos Penales José María Lidón, 2016, pp. 288-295. 
Esta situación actual no es implantada desde hace poco tiempo, sino que por el contrario, se viene arrastrando siglos atrás.

"A ocho escasos kilómetros del calabozo de la villa donde se dice que Miguel de Cervantes comenzó a escribir su novela se alinean a lo largo del antiguo Canal del Gran Prior, en el margen de una pequeña ciudad llamada Tomelloso, 12 casitas de colores con una luz sobre el dintel de sus puertas que despierta en la caída de la tarde manchega para informar al caminante, quizás cómo homenaje ignorado a las antiguas maisonscloses francesas, de la disponibilidad de sus habitadoras, mujeres prostitutas, de distintas nacionalidades, que ofrecen sus dones a cambio de dinero y que, desde el siglo XIX, como ha ocurrido en otras zonas españolas, han superado regulaciones y aboliciones manteniéndose hasta hoy"

Esta descripción y su historia pueden servir como ejemplo de la situación social de la prostitución en toda España. Una actividad no penalizada según la legislación actual que es fuente de debate en foros sociales y políticos tratando de implantar un modelo ideal que proteja a aquellas personas que la ejercen y elimine aquello que las daña.

Podemos afirmar que nos encontramos ante un fenómeno dinámico que varía según la influencia de la legislación, de los cambios económicos, políticos y sociales y contiene un amplio abanico de actitudes que vulneran los derechos humanos, como pueden ser la trata de personas y de niños, malos tratos, pobreza, explotación sexual, aislamiento, marginación, falta de seguridad sanitaria y social, etc.

En España se ha debatido durante siglos entre los distintos modelos o posicionamientos jurídicos existentes. Este debate comenzó hacia el siglo XIII en el que la prostitución se encon-

7 Confróntense al respecto, CARRETERO, Biblioteca Digital de la UNED, p. 1; CARRETERO, Revista de Estudios Superiores a Distancia Universidad Abierta, 2008; GUEREÑA, La prostitución en la España contemporánea, 2003, pp. 15-16. 
traba consentida, controlada y reglamentada por los poderes políticos y religiosos, en base al mantenimiento del bien común a partir de lo que se conoce como "el mito del desahogo", un mito que entra dentro de los sistemas de legitimación de la prostitución favoreciendo el desahogo del considerado, aún hoy en muchos ámbitos, incontrolable instinto masculino responsable, al ser reprimido, de actos violentos contra la mujer y el orden público ${ }^{8}$.

A partir del siglo XVI, fruto de desacuerdos en los planteamientos sobre el tema, se produce un vaivén en las medidas reguladoras, pasando de una legislación abolicionista en el siglo XVII hasta el XIX y de nuevo, una legislación tolerante y reglamentarista, de principios a mediados del siglo XIX, en un intento, por regular sus condiciones de funcionamiento en base a dos aspectos importantes: policiales, por la voluntad de erradicar el desorden social, y médicos, por la preocupación entre los higienistas del contagio de las enfermedades venéreas que desataron epidemias, a finales del siglo XV y del XVIII, mermando la población española. Ambos planteamientos fueron gestando la nueva normativa sobre la prostitución cuyas medidas fundamentales, fueron en aquella época, el censo, el control policial de la población dedicada a la prostitución y la obligación para ellas de revisiones médicas periódicas, considerándose esta nueva reglamentación, el resultado de un compromiso estratégico entre los sectores de poder, familia y Estado, asentados sobre las bases de vigilancia y disciplina social.

Ya durante la Guerra Civil se dio una permisividad relativa dependiendo del bando del que se tratase y en 1956 se prohíbe esta práctica en toda España, con la entrada en vigor del Decreto-ley de 3 de marzo sobre abolición de centros de tolerancia y otras medidas relativas a la prostitución, decreto de carácter abolicionista, y que permitió calificar la prostitución de

8 Véase al respecto, MARINA, "Lucha por la dignidad", Ponencia del Congreso Internacional Derechos Humanos y Prostitución, Ayuntamiento de Madrid, 2006, pp. 57-58. 
tráfico ilícito, apoyados a su vez en la Convención Internacional para la Represión de la Trata de Seres Humanos y de la Explotación de la Prostitución, aprobada por la Asamblea de las Naciones Unidas en $1949^{9}$. Mayoritariamente se opinaba que dicha decisión se apoyaba en la necesidad de España de dar un paso para reforzar su aspiración de ingreso en la ONU. Según otros, a ese hecho, sin duda cierto, se sumó la gran presión desplegada por la Iglesia Católica ${ }^{10}$.

Sin embargo, a pesar de esto, en la actualidad, la prostitución se continúa ejerciendo y tolerando en muchos ámbitos, sin que haya disminuido su proliferación ni siquiera a partir del fenómeno de la liberación sexual, en los años 60 y 70, sino aumentando su práctica, sobre todo, a partir del desarrollo del turismo y de las comunicaciones llegando, en el año 2008, a pagarse al día un millón de servicios sexuales en una realidad que contenía entre 400.000 y 500.000 mujeres dedicadas a la prostitución, siendo decisivo para su desarrollo el auge y el despliegue de internet puesto que la mayor parte de los servicios se ofertaban, tanto a través de la red como de la prensa diaria, estimándose que se podían publicar diariamente entre cuatrocientos y quinientos anuncios, convirtiéndose en un negocio que movía, solo en España dieciocho millones de euros al año, según estimaciones del Gobierno Central en $2009^{11}$.

Las distintas propuestas que han surgido en los últimos años, para definir una postura reglamentada sobre el comercio sexual han fracasado una tras otra. En 2007, el Congreso rechazó la posibilidad de regular o prohibir tajantemente, al considerar que distinguir el tráfico de personas y la prostitución es muy complicado. Según la Comisión Parlamentaria ambas cosas son fenómenos ligados y relacionados que no pueden separarse. Por ello, se aprobaron medidas para luchar contra la trata, se amplia-

9 Véase al respecto, CARRETERO, Biblioteca Digital de la UNED, p. 3.

10 En este sentido, QUINTERO OLIVARES, en VILLACAMPA ESTIARTE (coord.), Prostitución: ¿hacia la legalización?, 2012, pp. 175-176.

11 Consúltese al respecto, CARRETERO, Revista de Estudios Superiores a Distancia Universidad Abierta, 2008. 
ron las penas a los explotadores y las mafias y se creó el Plan Integral de Lucha contra la Trata, que recoge ayudas y apoyo a las mujeres explotadas por las mafias ${ }^{12}$.

La conclusión de esta evolución histórica de vaivenes entre la prohibición y la reglamentación, es que pese a los numerosos cambios acontecidos la situación parece haberse estancado y permanecer en la incertidumbre.

No cabe duda de que la conducta penalmente perseguida continúa siendo la explotación de la prostitución ajena, o proxenetismo, exista o no consentimiento por parte la víctima, sin embargo la regulación del ejercicio de la prostitución libremente ejercida, sigue estando ausente a día de hoy ${ }^{13}$. Se prioriza la actuación para proteger a aquellas personas que ejercen la prostitución obligadas y a las que se consideran todas como víctimas sin contemplar que un número indeterminado pueda realizarla de manera no forzada.

En ningún caso se persiguen aquellos supuestos en los que un sujeto ejerce la prostitución de forma independiente de cualquier otra que pudiese lucrarse por ello. Es decir, la prosti-

12 Véanse en este sentido, Comisión mixta de los derechos de la mujer y de la igualdad de oportunidades. Informe de la Ponencia sobre la prostitución en nuestro país, núm. 154 aprobada en sesión de la ponencia, de 13 de marzo de 2007; CARRANCO/SAHUQUILLO, "La prostitución, mejor debajo de la alfombra", El País, 2012. (Consultar http://sociedad.elpais.com/sociedad/2012/05/31/vidayartes/1338491745 774783.html; última visita el 11 de enero de 2018).

13 Según, NAVAlPOTRO BALlESTEROS, “así, el Capítulo V del Título VIII del Código penal, bajo la rúbrica "De los delitos relativos a la prostitución y la corrupción de menores", tipifica lo que se ha venido a denominar conductas periféricas al ejercicio de la prostitución, protagonizadas por personas que influyen en diversas circunstancias y con distintas condiciones a su ejercicio por terceros. Fuera de estos casos, la doctrina y la jurisprudencia suelen afirmar que se trata de una actividad tolerada, en cuanto que exenta de regulación, sobre la base del principio de que lo que la Ley no prohíba expresamente, se entiende permitido", "Las opciones jurídicas al alcance del Ayuntamiento de Madrid para mitigar las molestias a los vecinos y residentes derivadas del ejercicio de la prostitución, Ayuntamiento de Madrid", Anuario de Derecho Municipal, 2007, p. 328. 
tución en estos casos no ha sido ni es delito, a diferencia de lo que ocurre en otros países. En España, una vez desaparecida la vieja Ley de Peligrosidad Social no existe argumento jurídico alguno en contra de la libertad para la práctica de la prostitución. Pero sabemos que esto es una media verdad, que pretende confundir lo legítimo, lo legal y lo indiferente o irrelevante para el Derecho. Y al igual que no se prohíbe, tampoco se reconoce. En palabras de Quintero Olivares, "nunca se ha planteado la invocación doble del derecho del trabajo y el derecho a prostituirse sí así lo decide una persona como opción de trabajo. Cuando se dice que la práctica de la prostitución no puede ser reprimida porque eso iría en contra del contenido del derecho fundamental a la libertad, en realidad, lejos de estar ante una proclamación de respeto a quien tome esa determinación en su vida, lo único que tenemos es una muestra de lectura sesgada o hipócrita de la Constitución, que es la que hasta ahora hemos tenido y que sirve para dar fundamento a la abstención de represión por parte del Derecho, pero que deja en la oscuridad y en la indefinición jurídica esa actividad"14.

En resumen, el tema de la prostitución no está resuelto de forma satisfactoria en nuestro ordenamiento a nivel estatal y se siguen manteniendo dos posturas encontradas, por un lado los partidarios de la legalización como una actividad económica más y por otro lado, los partidarios de su prohibición, por considerarla una explotación sexual de las mujeres ${ }^{15}$.

La ausencia de regulación estatal sobre esta materia hasta este momento, permite a los distintos municipios politizar al respecto. Algunos políticos optan por perseguir la prostitución a través de ordenanzas municipales ${ }^{16}$, las cuales se caracterizan,

14 En este sentido, QUINTERO OLIVARES, en VILLACAMPA ESTIARTE (coord.), Prostitución: ¿hacia la legalización?, 2012, pp. 159-160.

15 En esta línea, CARMONA CUENCA, en SERA CRISTOBAL (coord.), Prostitución y trata: marco jurídico y régimen de derechos, 2007, pp. 59 y ss.

$16 \mathrm{Al}$ respecto, PEMÄN, J., "la política de civismo en los ayuntamientos españoles. Entre policía, acción social y educación cívica”, “...las ordenanzas municipales que desde los primeros años 2000 se han aprobado en multipli- 
por regla general, por sancionar a clientes y prostitutas en las calles. Es decir, si bien, la legislación estatal no mostraba una total inclinación, ni por el abolicionismo, ni por la legalización, la normativa municipal se decanta claramente por una política abolicionista y sancionadora, e incluso podría decirse que se declina más por el prohibicionismo ${ }^{17}$.

Es fundamentalmente, a través de esta normativa como, en defensa de una supuesta preservación del espacio público como ámbito de convivencia y civismo, con el objetivo de evitar las conductas que puedan perturbar dicha convivencia y evitar la exposición de trabajadores del sexo ante los menores y el resto de la sociedad; se prohíbe tanto el ofrecimiento, la solicitud, la negociación y la aceptación de servicios sexuales en la vía pública, así como la práctica de relaciones sexuales en la misma ${ }^{18}$.

cidad de municipios españoles no son tan novedosas, pues conectan con una antigua tradición que tiene que ver con la arraigada competencia municipal sobre policía urbana y que se había plasmado en las antiguas ordenanzas de policía y buen gobierno.", Revista Aragonesa de Administración Pública, 2010, p. 11.

17 Como afirma QUINTERO OLIVARES, "una vez colocada la prostitución en esa tierra extramuros del derecho, se pasa a la proliferación de medidas administrativas orientas a dificultarla en todos los modos imaginables, con sus correspondientes contradicciones, comenzando por la simultánea clausura de burdeles a la vez que se otorgan licencias para la construcción de otros, a veces aún mayores, y en alguno de estos últimos casos, venciendo a través de la jurisdicción contenciosa la resistencia inicial del Ayuntamiento afectado", en VILLACAMPA ESTIARTE (coord.), Prostitución: ¿hacia la legalización?, 2012, p. 160.

18 Confróntese al respecto, VILLACAMPA/TORRES, RECPC, 2013, p. 5.En este sentido según, VILLACAMPA ESTIARTE, “en España el ejercicio del trabajo sexual no se halla normativizado, como es sabido. La ausencia de regulación de esta actividad se conjuga con la criminalización de determinadas conductas aledañas a su ejercicio que implican la explotación de la persona prostituida. Sin embargo, la ausencia de regulación del ejercicio de esta actividad no impide que, más allá de la criminalización de determinadas conductas, no haya existido normativa en nuestro país que haya permitido la sanción en vía administrativa tanto de las trabajadoras sexuales que ofertan sus servicios en la calle cuanto, en menor medida, de los clientes que compran sus servicios", REPC, 2015, pp. 414-455. 
Muchos son los municipios que se han sumado a esta política de sancionar administrativamente a trabajadores sexuales y clientes, desde que Barcelona aprobara su Ordenanza de medidas para fomentar y garantizar la convivencia ciudadana en el espacio público el 23 de diciembre de 2005. Entre ellos se encuentran Sevilla, Murcia, Málaga, Valencia, Madrid, Bilbao, Albacete, Pontevedra, Granada o Badajoz.

Algunas de estas ordenanzas sólo sancionan la conducta de los clientes, es decir, se basan en el modelo sueco de la prohibición de compra de servicios sexuales, adoptando una medida claramente abolicionista. Sin embargo, la mayoría de ellas sancionan, además de a clientes, a prostitutas, de esa forma podemos afirmar que España a través de las políticas municipales y autonómicas ${ }^{19}$, está adoptando un sistema, que podría definirse como pseudo-prohibicionista, ya que sancionan a trabajadores del sexo, con sanciones administrativas ${ }^{20}$.

España parece optar por la política de un impreciso abolicionismo, que consiste, como primera medida, en no legalizar pero tampoco criminalizar, dejando la cuestión en una insoportable indefinición de modo que la prostitución, de acuerdo con esa extraña contemplación legal, no es ni lícita ni ilícita ${ }^{21}$. Las

19 Entre ellas, la Ley 11/2009, de 6 de julio, de regulación administrativa de los espectáculos públicos y las actividades recreativas o el Texto Refundido de Ley de Carreteras aprobado por Decreto Legislativo 2/2009, de 25 de agosto.

20 Véanse al respecto, ARELLA/ FERNANDEZ/NICOLAS/VARTABEDIAN, Los pasos (in) visibles de la prostitución, 2007, p. 8; VARTABEDIAN, Quaderns-e InstitutCatalàd'Antropologia, 2013, p. 80; VILLACAMPA/TORRES, RECPC, 2013, p. 6.

21 En este sentido, GRACIA RETORTILLO, "el ejercicio de la prostitución se encuentra hoy, en términos generales, en una situación de "vacío normativo", en la medida en que dicha actividad no es ilegal pero tampoco está claramente reconocida como actividad laboral. Se da una situación de tolerancia administrativa de la actividad, que, sin embargo, coexiste con una importante regulación en el orden penal, relativa a conductas relacionadas con la prostitución", Estudios QDL, Universidad de Barcelona, 17 de Junio de 2008, p. 107. No obstante, también se ha defendido la posibilidad de que en España existe hoy una prohibición del ejercicio de la prostitución en 
consecuencias de esta indecisión legislativa se plasman en hechos sabidos, si bien no es ilícito, la persona prostituta tampoco tiene reconocido su trabajo como legítimo ${ }^{22}$.

No obstante, en marzo de 2015, se aprobó la Ley Orgánica 4/2015, de 30 de marzo, de protección de la seguridad ciudadana, la cual entró en vigor el 1 de julio de 2015.

Dicha Ley ha dado un cambio radical al panorama estatal que se vivía hasta entonces. Como hemos indicado anteriormente, hasta la entrada en vigor de esta nueva Ley, la actividad de la prostitución no contaba con ninguna legislación estatal, únicamente se podía perseguir a clientes y prostitutas, en vía administrativa, a través de las mencionadas ordenanzas municipales sin embargo tras la entrada en vigor de la Ley de protección de seguridad ciudadana, la cobertura para atacar a este sector es mucho más amplia.

Si bien la regulación penal no ha sufrido cambios hasta el momento, con respecto a la situación legal de las personas que ejercen la prostitución, es decir, solo se persigue la explotación sexual por parte de terceros tanto si media como si no el consentimiento de la persona prostituta; la regulación a través de las sanciones administrativas se ha extendido no solo a nivel local y municipal, sino también estatal. De tal modo que, aunque sin existir un precepto legal que tipifique como delito la prostitución como actividad ejercida independientemente, la realidad no es del todo así, puesto que los trabajadores sexuales se ven atacados y perseguidos no solo por las ordenanzas que ya existían sino que a todo ello se une la aplicación de la nueva Ley Orgánica 4/2015, empeorando aún más, si cabe, su situación de vulnerabilidad y estigmatización.

virtud del Decreto ley de 3 de marzo de 1956, por el que se ordenó el cierre de las mancebías y casas de tolerancia y que no ha sido objeto de derogación explicita. Argumento defendido por, VERA FERNÁNDEZ-SANZ, Actualidad Administrativa, 2006, pp. 2180-2187.

22 En este sentido véase, QUINTERO OLIVARES, en VILACAMPA ESTIARTE, Prostitución: ¿hacia la legalización?, 2012, pp. 159. 
A continuación estudiaremos el contenido y desarrollo de alguna normativa que ha politizado sobre la prostitución en sus distintos municipios, para conocer el alcance y los objetivos que pretenden, siguiendo en su gran mayoría el sistema pseudoprohibicionista $^{23}$.

\section{II.Ordenanzas municipales prohibicionistas}

A nivel local los distintos Ayuntamientos han sido los encargados de elaborar ordenanzas municipales que regulan el régimen establecido en cada ciudad con respecto al ejercicio de la prostitución. De esta forma los municipios, con carácter general, han legislado al respecto partiendo de la idea de preservación del espacio y orden público, del mantenimiento de una adecuada convivencia ciudadana en condiciones de civismo y que permita a todos los ciudadanos el libre disfrute sin que haya acciones o conductas por parte de terceros que puedan perturbar ese disfru$t^{24}$. Marcando como meta este objetivo, todas han desarrollado una política común desde una perspectiva del fenómeno de la prostitución como una actividad perjudicial para lograr ese objetivo. No obstante no todos los Ayuntamientos han decidido darle la misma consideración a la persona que ejerce la prostitución, de modo que mientras para algunos esta persona es responsable del perjuicio ocasionado y por consiguiente es perseguida y sancionada, para otros, es una mera víctima que hay que proteger y librar de una posible sanción. En definitiva, lo que podemos deducir es que a nivel local existen dos tendencias claramente diferenciadas, por un lado existen las ordenanzas que responden a las bases del modelo prohibicionista, y por otro lado, encontramos ordenanzas que se fundamentan en los principios del abolicionismo.

23 Sobre este término consúltese, VARTABEDIAN, Oñati Socio-legal Series, 2011, pp.1-13.

$24 \mathrm{Al}$ respecto véanse, GRACIA RETORTILLO, Estudios $Q D L$, Universidad de Barcelona, 17 de Junio de 2008, p. 102; MERINO ESTRADA, Revista de estudios de la administración local y autonómica, 2006, pp. 491-492. 
A continuación analizaremos algunas de esas ordenanzas que pudieran ser prohibicionistas, frente a aquellas que responden al modelo abolicionista.

\subsection{Ayuntamiento de Barcelona}

Atendiendo al primer grupo, encontramos la Ordenanza de medidas para fomentar y garantizar la convivencia ciudadana en el espacio público de Barcelona ${ }^{25}$, que el Ayuntamiento de Barcelona aprobó en diciembre de 2005, y fue desarrollada en 2010 , por la nueva ordenanza del procedimiento sancionador ${ }^{26}$.

Esta ordenanza se dicta, en desarrollo directo de la Carta Municipal, aprobada por la Ley 22/1998, de 30 de diciembre $^{27}$, que previó la posibilidad de que el Ayuntamiento regulara, mediante ordenanza, una serie de conductas que se califican de infracción administrativa y que tienen relación directa con la gestión del espacio público y su uso y disfrute por la ciudadanía.

Tal y como muestra la exposición de motivos de dicha ordenanza ${ }^{28}$, "el objetivo principal de ésta, es el de preservar el espacio público como un lugar de convivencia y civismo, en el que todas las personas puedan desarrollar en libertad sus actividades de libre circulación, de ocio, de encuentro y de recreo, con pleno respeto a la dignidad y a los derechos de los demás y a la pluralidad de expresiones y de formas de vida diversas existen-

25 Aprobada por el Plenario del Consejo Municipal del Ayuntamiento de Barcelona, en sesión de 23 de diciembre de 2005; Publicación en el BOP de fecha 24/01/2006. Modificada el 29 de abril de 2011; Publicación en el BOP de fecha 12/05/2011 y modificada nuevamente el 25 de julio de 2012; Publicación en el BOP de fecha 16/08/2012.

26 Aprobada por el Plenario del Consejo Municipal del Ayuntamiento de Barcelona, en sesión de 26 de marzo de 2010. Publicación en el BOP en data 24/04/2010.

27 Modificada por la Ley 18/2014, del 23 de diciembre, de modificación de la Carta municipal de Barcelona.

28 Véase http://ajuntament.barcelona.cat/ordenances/sites/default/files/pdf/ Convivencia_0.pdf, última visita 24 de agosto de 2017. Confróntese al respecto, JIMÉNEZ ASENSIO, Fundación Democracia y Gobierno Local, 2005, pp. 71-72. 
tes en Barcelona". Se suma, pues, y en algunos aspectos actualiza y mejora, a las previsiones ya contenidas en otras ordenanzas actualmente vigentes, y que se refieren también, de una manera u otra, y desde diversas vertientes, al complejo fenómeno de la convivencia, como por ejemplo, y entre otras, la Ordenanza sobre el Uso de las Vías y los Espacios Públicos, del año 1998, o la Ordenanza General de Medio Ambiente, del año $1999^{29}$.

Se propone, precisamente, dar una respuesta democrática y consensuada a las nuevas problemáticas surgidas alrededor de determinados usos poco respetuosos o conflictivos de las calles de la ciudad.

No obstante, pese a esta finalidad que pudiéramos definir como general, no es la única que persigue, de tal modo que en el párrafo tercero de la citada exposición de motivos se indica que la Ordenanza también prevé mecanismos para impedir la explotación de las personas mediante la prostitución y a su vez evita que el ejercicio de la prostitución en la calle afecte a la convivencia ciudadana, estableciendo al mismo tiempo medidas sociales como pueden ser, el Programa para el Abordaje Integral del Trabajo Sexual y la Agencia, que deben dar salida a la situación actual" ${ }^{\prime 30}$.

29 Consultar texto integro, "Ordenanza de medidas para fomentar y garantizar la convivencia ciudadana en el espacio público de Barcelona".

30 Esta agencia ayudó a encontrar trabajo durante el año 2012 a mujeres a través de sus programas de inserción laboral. Además se firmaron 126 contratos. Estas cifras supusieron un aumento del 50\% respecto del año 2011. Durante el año 2012 inició diversos programas de formación y de inserción laboral coordinándose con las entidades del tercer sector. Entre esos programas destaca el de Mujer y Prostitución, este proyecto tiene como objetivo mejorar la calidad de vida de las personas que se dedican a la prostitución a través de la formación y la inserción socio-laboral. Los datos estadísticos proporcionados por la agencia reflejan un numero de 127 mujeres que participaron en actividades formativas durante el año 2012, un 38\% más que el año anterior, entre las que se encuentran: clases de catalán y castellano, curso de camareras de piso, talleres de salud básica y alimentación infantil, talleres de economía doméstica, talleres de orientación laboral y talleres de cuidado de personas mayores. Véanse al respecto, RedaccióBcn. cat, Ayuntamiento de Barcelona, 2013. (Consultar https://w110.ben.cat/por- 
En consecuencia, podríamos resumir a grandes rasgos, que la política adoptada en Barcelona y desarrollada a través de dicha ordenanza justifica su existencia en el mantenimiento del orden público y la convivencia cívica de los ciudadanos evitándoles la posible perturbación del disfrute de las zonas comunes ${ }^{31}$, provocando un cambio en el panorama de la ciudad, posicionándose en un prohibicionismo radical respecto a la prostitución ejercida fuera de los locales habilitados para ello ${ }^{32}$.

En su voluntad de ordenar la convivencia ciudadana, el Ayuntamiento de Barcelona ha optado por regular el ofrecimiento y demanda de servicios sexuales en el espacio público. Por tanto, la adecuada comprensión del alcance de esta regulación debe partir de una idea previa, y es que la Ordenanza no quie-

tal/site/ServeisSocials/menuitem.7292db498a2803aaca63ca63a2ef8a0c/ index0d05.html?vgnextoid=614bf6367cb5f310VgnVCM1000001947900a $\underline{\text { RCRD\&vgnextfmt }=\text { formatDetall\&vgnextchannel }=80445 \mathrm{ab} 6 \text { eaebb2 } 10 \mathrm{Vg}}$ nVCM10000074fea8c0RCRD\&lang=es ES, última visita 15 de enero de 2018); PEMÁN GAVÍN, Revista de Estudios de la Administración Local y Autonómica, 2007, pp. 39-40.

31 Estos mismos argumentos son utilizados como justificación de otras muchas políticas locales, como sucedió en el caso del Ayuntamiento de Madrid en el año 2004, aunque con otro signo político y con otra letra, puesto que nunca llegó a convertirse en ordenanza municipal, la búsqueda de resultados era la misma. El Ayuntamiento de Madrid puso en marcha su Plan contra la esclavitud sexual en abril de 2004. En teoría la intención explicitada por Ana Botella era luchar contra las situaciones de esclavitud que padecían las mujeres que ejercían la prostitución en las calles de nuestra ciudad. El Plan proponía acabar con este tipo de prostitución, ofreciendo a las prostitutas dejar este trabajo e incorporarse a planes de reinserción cobrando 300 euros mensuales o la vuelta a su país de aquellos inmigrantes que no tenían regularizada su situación en este país. También apareció una campaña dirigida a los clientes bajo el lema "Porque tú pagas, existe la prostitución. No colabores en la explotación sexual de seres humanos", campaña que iba acompañada de una actuación de persecución y toma de datos de todos aquellos clientes de la prostitución de calle. (Consultar en http://www.feministas.org/ IMG/pdf/ordenanzas Silvi.pdf. última visita 15 de enero de 2018).

$32 \mathrm{Al}$ respecto confróntense, POYATOS I MATAS, La prostitución como trabajo autónomo, 2009, p. 35; VILLACAMPA ESTIARTE/TORRES, $R E$ $C P C, 2013$, p. 6. Véanse al respecto, STSJ Cataluña. Sala de lo Contencioso, 474/2006; STSJ Cataluña. Sala de lo Contencioso, 83/2010. 
re ser una regulación de la prostitución genéricamente considerada, puesto que seguramente el municipio no tendría título competencial para hacerlo, sino que la intervención normativa municipal pretende limitarse a establecer una regulación de la ocupación del espacio público para realizar las actividades de ofrecimiento y demanda de servicios sexuales (artículo 38.2). Así entendida, la Ordenanza quiere regular infracciones y establecer sanciones en la medida en que las conductas contempladas perjudiquen la convivencia ciudadana y el uso adecuado de los espacios públicos. No obstante, el artículo 38.1, al definir los fundamentos legales de la regulación, enumera una serie de aspectos que parecen ir más allá de este propósito y se refiere, junto a la protección de la convivencia y la vialidad del tránsito público, a la protección de los menores o la lucha contra la explotación de determinados colectivos ${ }^{33}$.

Esta normativa regula una gran variedad de comportamientos o actuaciones que podrían resultar perjudiciales para una convivencia cívica y tranquila, manteniendo intacta la dignidad humana. Estas normas de conductas en el espacio público quedan reguladas en el Título II de esta Ordenanza. Son un amplio abanico de conductas que varían desde aquellas que atenten directamente contra la dignidad de las personas, cuyo fundamento, constitucional y legal es la necesidad de evitar en el espacio público todas las prácticas individuales o colectivas que atenten contra la dignidad de las personas, así como las prácticas discriminatorias de contenido xenófobo, racista, sexista, homófobo, o de cualquier otra condición o circunstancia personal, económica o social, especialmente cuando se dirijan a los colectivos más vulnerables ${ }^{34}$; las conductas que provoquen una degradación visual del entorno urbano, fundamentada en el derecho a disfrutar del paisaje urbano en la ciudad, que va de la mano del deber de

33 Véase al respecto, GRACIA RETORTILLO, Estudios $Q D L$, Universidad de Barcelona, 17 de Junio de 2008, p. 120.

34 Artículo 15 de la Ordenanza de medidas para fomentar y garantizar la convivencia ciudadana en el espacio público de Barcelona. 
mantenerlo en condiciones de limpieza, pulcritud y decoro ${ }^{35}$; o el uso inadecuado del espacio público para juegos, entre otros.

Con respecto al tema que nos interesa abordar, en el capítulo quinto, sección segunda de la ordenanza, se regulan las conductas relativas a la utilización de espacios públicos para el ofrecimiento y demanda de servicios sexuales.

La regulación de estas conductas como infracción persigue preservar a los menores de la exhibición de prácticas de ofrecimiento o solicitud de servicios sexuales en la calle, mantener la convivencia y evitar problemas de vialidad en lugares de tránsito público y prevenir la explotación de determinados colectivos $^{36}$.

De acuerdo con lo establecido anteriormente, las conductas que se castigan y que quedan prohibidas son:

En primer lugar, bajo catalogación de infracción leve, el mero ofrecimiento o la aceptación, de una prestación de servicios sexuales retribuidos en el espacio público cuando estas prácticas excluyeran o limitasen la compatibilidad de los distintos usos del espacio público. Es importante señalar al respecto, que tanto el acto de ofrecer como el de aceptar una prestación de servicios sexuales recaen evidentemente sobre la persona prostituta. Además debemos añadir que esta normativa no establece en ningún caso qué se engloba dentro del término "prestación de servicios sexuales", dejando un margen de interpretación muy amplio.

A estas conductas también se añaden la solicitud, la demanda y la negociación de servicios sexuales retribuidos en el espacio público por parte de los clientes potenciales ${ }^{37}$, tal y

35 Artículo 19 de la Ordenanza de medidas para fomentar y garantizar la convivencia ciudadana en el espacio público de Barcelona.

36 Artículo 38 de la Ordenanza de medidas para fomentar y garantizar la convivencia ciudadana en el espacio público de Barcelona.

37 Expresión incorporada tras la modificación de 2010, a partir de las alegaciones presentadas en el trámite de información pública por el Grupo Municipal de CIU en cuanto al desdoblamiento en la tipificación de las conductas de ofrecimiento y de demanda de servicios sexuales. 
como establece el artículo 39 de la Ordenanza ${ }^{38}$, bajo catalogación de infracción grave. En este sentido, el propio artículo se encarga de atribuir estas conductas a los posibles clientes de la prostitución.

Por otro lado, también se prohíbe, considerando como infracción grave, cualquier conducta que tenga lugar en el espacio público que favorezca y promueva el consumo de prostitución u otras formas de explotación sexual, considerando entre estas, las conductas consistentes en acercar a los clientes, aunque nuevamente regula de forma amplia, sin delimitar en qué deben consistir esas conductas.

Finalmente está especialmente prohibido mantener relaciones sexuales mediante retribución en el espacio público, lo cual constituiría una infracción muy grave.

Ahora bien, de cualquier modo, serán sancionadas cualquiera de las conductas anteriores cuando se lleven a cabo en espacios situados a menos de 200 metros de distancia de centros docentes o educativos en los que se imparten enseñanzas del régimen general del sistema educativo ${ }^{39}$.

38 Ver el artículo 39 de la Ordenanza de medidas para fomentar y garantizar la convivencia ciudadana en el espacio público de Barcelona. Modificado el 25 de julio de 2012. Publicada en el BOP el 16 de agosto de 2012. Sobre esta modificación, GONZALEZ DEL RÍO, "reforma que ha permitido interponer sanciones más graves a los clientes de la prostitución y a las personas que favorecen el consumo de la prostitución en la calle", El ejercicio de la prostitución y el derecho del trabajo, 2013, p. 62.

39 Al respecto según, VARTABEDIAN, "esta referencia es muy ambigua y susceptible de actuaciones arbitrarias ya que por "centro educativo" se puede pensar en las universidades donde no hay presencia infantil y los/as estudiante ya son mayores de edad. Además, esta prohibición de permanecer a menos de doscientos metros de escuelas o demás centros de enseñanza, sin establecer una franja de horario para la prohibición, ha dado lugar a que, en más de una ocasión, se multara a trabajadoras del sexo por situarse a una distancia inferior en horarios nocturnos, en los que (una vez más), no está en peligro la sensibilidad de los menores", Oñati Socio-legal Series, 2011, p. 9. Véase también al respecto, ARELLA, en VALIÑO, (coord.), Defender y repensar los derechos sociales en tiempo de crisis, Barcelona: Observatori DESC, 2009, pp. 81-88. 
Si bien es cierto que el Ayuntamiento catalán ha focalizado su actuación sancionadora sobre el cliente, esto no implica la exclusión de sanciones para quienes ejercen la prostitución. Ya sean con sanciones leves o con medidas alternativas que sustituyan esa sanción ${ }^{40}$. De esta manera observamos, como ya apuntábamos al comienzo, un color claramente prohibicionista en esta política catalana, pues como ya pudimos ver en el capítulo anterior, es un modelo que no solo persigue al cliente de la prostitución sino que de igual modo sanciona y culpabiliza al trabajador sexual.

Con respecto al artículo 40, que regula el régimen sancionador, establece que "las conductas clasificadas como leve, es decir, ofrecer o aceptar prestar servicios sexuales retribuidos en el espacio público, serán sancionadas con multas desde 100 a 300 euros. Cuando se realicen a menos de doscientos metros de centros de enseñanza, las multas oscilaran desde 300,01 a 750 euros. Por su parte las conductas consideradas graves serán sancionadas con multas desde 1.000 a 1.200 euros, y cuando tengan lugar a menos de 200 metros de distancia de centros docentes, oscilaran desde los 1.200,01 euros a los 1.500 euros, estas conductas serán la solicitud, demanda y negociación de servicios sexuales retribuidos en el espacio público por parte de los clientes potenciales, y cualquier conducta que favorezca y promueva el consumo de prostitución u otras formas de explotación sexual, como las conductas consistentes en acercar a los clientes. Además de las sanciones a estas conductas leves y graves, las conductas muy graves, como mantener relaciones sexuales mediante retribución en el espacio público, serán sancionadas con multa

40 Consultar en la Sede electrónica del Ayuntamiento de Barcelona. http:// ajuntament.barcelona.cat/es/informacion-administrativa/normativa.al. $\mathrm{Al}$ respecto, VILLACAMPA ESTIARTE, "dicha modificación iba orientada a diferenciar las sanciones e infracciones aplicables a trabajadoras sexuales y clientes, con la finalidad de endurecer las correspondientes a los clientes; sin embargo, también las aplicables a las trabajadoras sexuales se vieron en parte endurecidas", REPC, 2015, p. 429. 
de $1.500,01$ a 3.000 euros"41. No obstante, en cualquier caso se podrá proceder a una reducción de la sanción a su importe mínimo si el pago se hace efectivo antes del inicio del procedimiento sancionador. Cuando la Ordenanza no fije el importe mínimo de la sanción que corresponda, la rebaja será del setenta y cinco por ciento de su importe máximo ${ }^{42}$.

Finalmente con respecto a la intervención social del Ayuntamiento, la ordenanza barcelonesa lejos de tener un carácter exclusivamente represivo para las prostitutas, no se limita a imponer sanciones ya que también prevé medidas que persiguen reinsertar a las personas que ejercen la prostitución en los espacios públicos de la ciudad ${ }^{43}$, todo ello a través de los servicios sociales competentes, así el artículo 41 de la Ordenanza, bajo el título de Intervenciones especificas, establece que este "prestará información y ayuda a todas aquellas personas que ejerzan el trabajo sexual en la ciudad y quieran abandonar su ejercicio. Los servicios municipales competentes, con el auxilio de los agentes de la autoridad, si es el caso, informarán a todas las personas que ofrecen servicios sexuales retribuidos en espacios públicos de las dependencias municipales y de los centros de atención institucional o de carácter privado, como asociaciones o ONG, a los que podrán acudir para recibir el apoyo que sea necesario para abandonar esas prácticas" ${ }^{\prime 4}$.

El Ayuntamiento de Barcelona, además aprobó el Plan para el Abordaje Integral del Trabajo Sexual ${ }^{45}$ a fin de evitar que

41 Véase el artículo 40 de la Ordenanza de medidas para fomentar y garantizar la convivencia ciudadana en el espacio público de Barcelona.

42 Artículo 92 de la Ordenanza de medidas para fomentar y garantizar la convivencia ciudadana en el espacio público de Barcelona.

$43 \mathrm{Al}$ respecto véase, GONZALEZ DEL RÍO, El ejercicio de la prostitución y el derecho del trabajo, 2013, p. 63.

44 Artículos 41.1 y 41.2 de la Ordenanza de medidas para fomentar y garantizar la convivencia ciudadana en el espacio público de Barcelona.

45 Véase el artículo 41.4 de la Ordenanza de medidas para fomentar y garantizar la convivencia ciudadana en el espacio público de Barcelona. "El Plan para el Abordaje Integral del Trabajo Sexual coordinará todas las actuacio- 
el ofrecimiento de servicios sexuales en la vía pública afecte a la convivencia ciudadana y poder atender a las personas que realicen estas actividades ${ }^{46}$. Y en este marco de actuación crea una agencia, para así, afrontar este fenómeno. Por su parte esta Agencia para el abordaje integral del trabajo sexual (ABITS), del Ayuntamiento de Barcelona, ha impulsado una guía para periodistas sobre cómo se debería tratar la información sobre prostitución y explotación sexual ${ }^{47}$. El Ayuntamiento de Barcelona

nes de servicios a las personas que realizan esta actividad en el espacio urbano, y en este sentido recogerá:

a) Colaborar y establecer convenios con entidades que trabajen con estos colectivos.

b) Informar sobre los servicios públicos disponibles y muy especialmente los servicios a las personas: servicios sociales, servicios educativos y servicios sanitarios.

c) Informar de los derechos fundamentales de estas personas.

d) Colaborar con las entidades referentes a esta materia para ofrecer nueva formación a las personas que integran este colectivo.

e)Informar y ofrecer los recursos laborales disponibles desde la Administración o en colaboración con las entidades referentes en la materia.

46 Según, VILLACAMPA ESTIARTE, "la efectividad de dicho Plan de Abordaje Integral ha sido puesto entredicho por autores como Vartabedian", $R E P C, 2015$, p. 430. Al respecto, VARTABEDIAN, "en la práctica este Plan no ofrece los resultados esperados ya que no cuenta con un presupuesto ni recursos suficientes para cumplir con sus objetivos mínimos. Además, no se pueden ofrecer verdaderas alternativas laborales a las trabajadoras sexuales inmigrantes en situación administrativa irregular ("sin papeles"), sobre todo. Los planes de inserción laboral tienen implícita la exigencia de que la persona (en este caso, la trabajadora sexual) tenga permiso administrativo para trabajar, puesto que no se trata sólo de formar, sino también de que puedan insertarse en el mercado laboral normalizado mediante un contrato de trabajo. Evidentemente, la puesta en marcha de este plan no ha reducido la presencia de trabajadoras sexuales en la calle, en consecuencia, no se refleja en la realidad los objetivos de carácter más "integrador" de este Plan", Oñati Socio-legal Series, 2011, pp. 1-13.

47 En este sentido, ABITS/ADPC, "Recomendaciones: Abordar el fenómeno de la prostitución en toda su complejidad social. Diferenciar entre la prostitución ejercida voluntariamente y la trata con fines de explotación sexual o la prostitución forzada. Hacer visibles a las personas que se lucran y/o delinquen a través de la prostitución así como a los usuarios que la hacen posible, retirando el foco mediático de las mujeres que la ejercen. Respetar la dignidad y la libertad de las mujeres que ejercen la prostitución y recha- 
quiere dar un paso más en la mejora del tratamiento informativo de la prostitución y del tráfico de seres humanos con finalidad de explotación sexual y en la promoción del tratamiento no sexista de las mujeres en los medios de comunicación y en la publicidad. Por este motivo, la Concejalía de Mujer y Derechos Civiles encargó a la Asociación de Mujeres Periodistas de Cataluña la elaboración de las recomendaciones, junto con un grupo de discusión formado por representantes de diferentes medios de comunicación, agencias de noticias, gabinetes de prensa institucionales y otras organizaciones y expertos vinculados tanto con el ámbito comunicativo como el de la prostitución ${ }^{48}$.

\subsection{Ayuntamiento de Murcia}

El Ayuntamiento de Murcia, aprobó en junio de 2011, la Ordenanza para luchar contra la prostitución en el municipio de

zar los discursos que atentan en contra. Evitar la reproducción de mitos y/o estereotipos sobre la prostitución. No banalizar, ni hacer sensacionalismo o apología en torno a la prostitución. No relacionar la prostitución con la delincuencia, la inseguridad y el incivismo, evitando ubicar, por defecto, las noticias en la sección de sucesos. Utilizar fuentes de información especializadas, dando voz y autoridad a las mujeres que ejercen la prostitución. Respetar la decisión de las mujeres que ejercen la prostitución en relación con la difusión de su identidad e imagen. Evitar que puedan ser identificadas sin su consentimiento. Hacer un uso no sexista de la lengua, tratando de manera equitativa a los distintos sujetos implicados. Efectuar la rectificación de cualquier información errónea publicada. Promover el rol de los gabinetes de comunicación como fuente de información específica para la contextualización de las noticias. Ofrecer formación en materia de género, prostitución y trata con fines de explotación sexual al colectivo de profesionales de la comunicación y a estudiantes del ámbito universitario. Impulsar la investigación y la difusión sobre el fenómeno de la prostitución y la trata con fines de explotación sexual. Difundir y hacer seguimiento del impacto de estas recomendaciones.", El tratamiento de la prostitución y la trata con fines de explotación sexual en los medios de comunicación. Recomendaciones, Ayuntamiento de Barcelona, 2006, pp. 10-27.

48 Véase, Ayuntamiento de Barcelona. (Consultar http://w110.bcn.cat/portal/site/ Dones/menuitem.de19ba4a7f0fe87b6306809220348a0c/?vgnextoid $=0601976$ 9d987b410VgnVCM1000001947900aRCRD\&vgnextfmt=formatDetall\&vgn extchannel $=0000000170957416$ VgnV6CONT00000000200RCRD\&lang=es ES, última visita el 01 de diciembre de 2017). 
Murcia $^{49}$. A diferencia de la normativa municipal barcelonesa, no se trata de una ordenanza que regula multitud de conductas infractoras que atentan contra el desarrollo adecuado de los espacios públicos, donde debe primar la convivencia, el civismo y la igualdad, sino que este texto se encarga de velar por este mismo objetivo aunque se basa más específicamente en materia de prostitución, como conducta que puede afectar al buen desarrollo de los principios de convivencia, civismo e igualdad.

En consecuencia, "el objetivo principal de esta Ordenanza es el de luchar contra la prostitución en el municipio de Murcia, preservando los espacios públicos como lugares de convivencia, civismo e igualdad, evitando actividades de explotación sexual que difunden una imagen del ser humano, muy especialmente de la mujer, como mero objeto sexual y perturban la convivencia social" ${ }^{\prime 50}$.

Según lo establecido en el artículo 1.2, esta Ordenanza "regula una serie de medidas encaminadas específicamente al fomento y a la promoción de la igualdad entre hombres y mujeres; identifica los bienes jurídicos protegidos; prevé medidas para fomentar la igualdad, detalla cuales son las normas de conducta que se prohíben y la sanción que corresponde por perturbar o lesionar la convivencia ciudadana".

Estos objetivos perseguidos por la citada Ordenanza, podrán ser cumplidos mediante el ejercicio de potestades de vigilancia, prevención, control e inspección de los actos y conductas que se describen ${ }^{51}$ y que analizaremos a continuación.

49 Aprobada por Comisión de Pleno de Cultura, Descentralización y Asuntos Sociales, en virtud de acuerdo de Pleno de delegación de competencias de 27 de junio de 2011, en sesión de 23 de septiembre de 2013. Publicada aprobación definitiva en el BORM núm. 234 de 8 de octubre de 2013. Corrección de error BORM núm. 234 de 19 de octubre de 2013. (Consultar http://www.murcia.es/documents/11263/242162/ORD PROSTITUCION. pdf, última visita el 26 de febrero de 2018).

50 Véase, la exposición de motivos de la Ordenanza para luchar contra la prostitución en el municipio de Murcia.

51 Artículo 3 de la Ordenanza para luchar contra la prostitución en el municipio de Murcia. 
Resulta importante determinar cuáles son los principios inspiradores de la citada Ordenanza, para así conocer cuál es su alcance. En este sentido se prohíbe toda discriminación por razón de sexo, ya sea directa o indirecta e independientemente de la forma utilizada para ello. No obstante, y según lo dispuesto en el texto, no se considerarán discriminatorias aquellas medidas que, aunque supongan un tratamiento diferente entre hombre y mujer, tienen una justificación objetiva y razonable, entre las que se pueden incluir las acciones positivas para las mujeres, al tratarse de un grupo de población que requiere un plus de protección por los condicionamientos económicos y sociales que modulan su situación y la violencia de género ejercida sobre ellas. Al igual que se persigue una no discriminación por razón de sexo, el texto añade que debe ofrecerse igualdad de oportunidades, es decir, que las medidas que se adopten deben ir orientadas a conseguir, desde la igualdad, el ejercicio efectivo por parte de mujeres y hombres de los derechos civiles, políticos, económicos, sociales, culturales y el resto que estén reconocidos por la Constitución, y las otras normas de nuestro ordenamiento jurídi$\mathrm{co}^{52}$. No obstante, añade que deben establecerse los medios necesarios para que esta consecución de la igualdad entre hombres y mujeres y la erradicación de la violencia de género se realice respetando tanto la diversidad y las diferencias existentes entre mujeres y hombres en cuanto a su biología, condiciones de vida, aspiraciones y necesidades, como a la diversidad y diferencias existentes entre los distintos grupos de mujeres ${ }^{53}$.

Esta Ordenanza incorpora la perspectiva de género de modo y forma que tiende a eliminar las desigualdades y promueve la igualdad de mujeres y hombres, teniendo en cuenta las diferentes situaciones, condiciones, aspiraciones y necesidades de mujeres en condición de explotación sexual. Para ello, se debe promover la eliminación de los roles sociales y estereotipos en

52 Véanse los artículos 6 y 7 respectivamente, de la Ordenanza para luchar contra la prostitución en el municipio de Murcia.

53 Según lo establecido en el artículo 8 de la Ordenanza para luchar contra la prostitución en el municipio de Murcia. 
función del sexo sobre los que se asienta la desigualdad y la violencia ejercida contra la mujer que tienden a tratar a las mujeres como un objeto de consumo, atentando contra los principios básicos de dignidad y respeto a las mismas. En este sentido, considera que la prostitución es una forma de materializar esa discriminación y violencia sobre las mujeres, y es por eso que marca una prohibición de la misma en la ciudad.

Una vez expuestos los objetivos marcados por esta normativa, así como los fundamentos a través de los cuales marcar esos objetivos, analizaremos las normas de conductas que a tenor del texto están prohibidas bajo sanción administrativa. En este sentido, en el Título II, Capítulo primero del texto se regulan las normas de conductas en el espacio público, más concretamente, las conductas que pudieran suponer un atentado contra la dignidad de las personas en situación de explotación sexual. Con respecto a las infracciones tipificadas en esta Ordenanza, se clasifican en leves, graves y muy graves ${ }^{54}$. Según esto:

Se considerarán infracciones leves, el ofrecimiento por parte de las personas que ejercen la prostitución, ya sea directa o indirectamente, de servicios sexuales retribuidos en los espacios y/o lugares descritos en el artículo 4 de la presente Ordenanza ${ }^{55}$ considerando que estas conductas, en cualquier caso, son incompatibles con los usos atribuidos a los mismos. Como se puede observar de este precepto, el sujeto infractor sería la persona que ejerce la prostitución, más la conducta que se atribuye a ésta y por la cual debe ser sancionada es la mera oferta de los servicios sexuales, sin que en ningún momento se indique en que pueden consistir esos servicios. Además tampoco queda delimitado el alcance de los mismos cuando utiliza los términos directa o indirectamente, sin añadir nada más. No obstante, cuando este ofrecimiento se realice en espacios situados a menos de trescien-

54 Ver el artículo 13 de la Ordenanza para luchar contra la prostitución en el municipio de Murcia.

55 Consultar el artículo 4 de la Ordenanza para luchar contra la prostitución en el municipio de Murcia. 
tos metros de distancia de centros docentes o educativos $u$ otros espacios con afluencia de público infantil y/o juvenil, así como, a menos de trescientos metros de lugares o alrededores de los mismos, con gran afluencia de público como puede ser cualquier acto público de naturaleza cultural, comercial, festiva, lúdica o deportiva, o de cualquier otra índole, la conducta de ofrecimiento, pasará de ser infracción leve a grave.

Por otro lado, también será sancionable el hecho de solicitar, negociar o aceptar, directa o indirectamente, servicios sexuales retribuidos en los espacios y/o lugares descritos en el artículo 4. En este caso, dichas conductas serán llevadas a cabo por las personas demandantes, es decir, por parte del cliente.

Además, el precepto añade que a estos efectos se considerará demanda, solicitud o aceptación, de la realización de una actividad sexual a cambio de un pago, tanto la proposición que se haga a la persona ejerciente, para el propio disfrute del solicitante, como la proposición para el disfrute de una tercera persona. En cualquier caso, lo que se prohíbe, bajo catalogación de infracción grave, es la acción de solicitar servicios sexuales a cambio de una contraprestación, con independencia de que se solicite para sí o para otra persona. En este caso cuando cualquiera de las conductas descritas se lleven a cabo en espacios situados a menos de trescientos metros de distancia de centros docentes o educativos $u$ otros espacios con afluencia de público infantil y/o juvenil, o en lugares o alrededores de los mismos, a menos de trescientos metros, con gran afluencia de público como puede ser cualquier acto público de naturaleza cultural, comercial, festiva, lúdica o deportiva, o de cualquier otra índole, la infracción que es grave, pasa a ser muy grave.

También será considerada infracción grave, mantener relaciones sexuales mediante retribución por ellas en los lugares indicados en el artículo 4. Además de la colocación, reparto, divulgación y/o difusión de publicidad que promueva o fomente el consumo de prostitución y la explotación sexual, el mercado de prostitución y el turismo sexual, en cualquiera de los ele- 
mentos que, conforme al artículo 4 de la presente Ordenanza constituyen el objeto de aplicación de la misma, o en cualquier otro elemento fijo o móvil.

Y por último la reiteración de dos o más infracciones leves en el transcurso de un año.

A todas estas prohibiciones, el precepto añade, bajo catalogación de infracción muy grave, la prohibición de conductas que puedan considerarse como favorecedoras del consumo de prostitución u otras formas de explotación sexual, con independencia de que sean constitutivas de infracción penal conforme a nuestro ordenamiento jurídico. Añade que a estos efectos se considerarán dentro de estas conductas de favorecimiento las consistentes en acercar a los clientes al lugar donde se encuentran las personas en situación de prostitución, y cualquier otra que sirva para el acercamiento entre ambas partes.

Teniendo en cuenta todas las normas de conductas susceptibles de ser sancionadas, podemos afirmar que los sujetos a los que se dirigen estas prohibiciones son por un lado las personas que ejercen la prostitución, y por otro los clientes de éstas, lo que nos permite a su vez, reconocer una clara tendencia prohibicionista en las letras de esta normativa. Ahora bien, éstos no son los únicos sujetos que pueden ser sancionados en virtud de esta Ordenanza, tal y como establece el artículo 19, si bien, todas aquellas personas que realicen alguna de las conductas tipificadas en la presente Ordenanza serán responsables directos de las sanciones previstas en la misma, en el caso de realización de las conductas de colocación, reparto, divulgación y/o difusión de publicidad que promueva o fomente el consumo de prostitución y la explotación sexual, el mercado de prostitución y el turismo sexual, serán responsables, además de los autores materiales de las mismas, las personas físicas o jurídicas que consten como anunciadores en el soporte de que se trate en cada caso. Por último podríamos añadir, que en lo que a las conductas de favorecimiento, consistentes en acercar a los clientes al lugar donde se encuentran las personas en situación de prostitución, respecta, 
el precepto no indica quien o quienes pueden ser los sujetos que las lleven a cabo, y por tanto, cabria interpretar que podría ser cualquier persona, desde la que ejerce la prostitución, hasta un tercero que facilite el contacto entre esta y el cliente.

Tras la redacción de las distintas conductas prohibidas por esta normativa y de los sujetos que responderán por su comisión, debemos establecer cuáles son las sanciones que llevan aparejadas esas infracciones, las cuales se regulan en el artículo 14. De este modo, las infracciones tipificadas como leves serán sancionadas como multas de hasta 750 euros, las tipificadas como graves, serán sancionadas con multas de 750,01 a 1.500 euros, y las sanciones impuestas a las infracciones muy graves, se corresponden con multas de 1.500,01 a 3.000 euros $^{56}$.

Ante el convencimiento del Ayuntamiento de Murcia del papel de las personas en la prostitución como víctimas de estas $\operatorname{conductas}^{57}$, al margen de la sanción, las mujeres que deseen abandonar el ejercicio de la prostitución y mejorar sus condiciones de vida, podrán acudir de forma voluntaria a los dispositivos de integración socio-laboral que se desarrollan por parte de los servicios municipales competentes u otros que el Ayuntamiento de Murcia ponga en marcha a través de medidas y programas de apoyo, formación y capacitación a través de las fórmulas que se establezcan a tal efecto ${ }^{58}$.

Según lo recogido en el artículo 15, el Ayuntamiento de Murcia, a través de los servicios municipales competentes, prestará información y ayuda a todas aquellas personas que se encuentren en situación de prostitución y/o explotación sexual en la ciudad. De igual modo, los servicios municipales competentes, con el auxilio de los agentes de la autoridad si fuera necesario, informarán a todas las personas que se encuentren en

56 Artículo 14 de la Ordenanza para luchar contra la prostitución en el municipio de Murcia.

57 Al respecto véase, VILLACAMPA ESTIARTE, REPC, 2015, p. 432.

58 Artículo 26: Medidas dirigidas a personas en prostitución, de la Ordenanza para luchar contra la prostitución en el municipio de Murcia. 
situación de prostitución y/o explotación sexual de todos aquellos recursos sociales, cualquiera que sea la titularidad de los mismos, que trabajan con este colectivo posibilitando el abandono de esta situación. En aquellos casos especialmente graves o urgentes, y con el único objeto de que la persona pueda recibir efectivamente y lo antes posible la atención social y/o médica requerida, los agentes de la autoridad $\mathrm{u}$ otros servicios competentes podrán acompañarla a los recursos sociales mencionados anteriormente. En este sentido, se entenderán que concurren circunstancias de gravedad o urgencia cuando se haya producido daño a las personas en situación de prostitución y/o explotación sexual o exista riesgo evidente de que pueda producirse.

Además el Ayuntamiento de Murcia colaborará intensamente en la persecución y represión de las conductas atentatorias contra la libertad e indemnidad sexual de las personas que puedan cometerse en el espacio público, en especial las actividades de proxenetismo o cualquier otra forma de explotación sexual, y muy especialmente, en lo relativo a los menores. En esta Ordenanza se prevé, una medida de gran alcance, o al menos debiera serlo, en el supuesto de que los ciudadanos cumplieran con la obligación, que también derecho, que en esta normativa se recoge. Según esto, todas las personas en Murcia tienen tanto el derecho como la obligación de colaborar con las autoridades municipales o sus agentes para prevenir la explotación sexual de las personas, cualquiera que sea el lugar donde se produzcan ${ }^{59}$.

\subsection{Ayuntamiento de Granada}

En el ayuntamiento granadino, también han decidido desarrollar una política municipal que vele por el mantenimiento de una adecuada convivencia ciudadana en su territorio, de esta forma se aprobó en 2009 la Ordenanza de medidas para fomentar la convivencia ciudadana en el espacio público ${ }^{60}$.

59 Véase el artículo 16 de la Ordenanza para luchar contra la prostitución en el municipio de Murcia.

60 Con fecha 25 de septiembre de 2009, el Excmo. Ayuntamiento Pleno ha adoptado el acuerdo núm. 766 relativo a la aprobación definitiva de Orde- 
El objetivo principal de esta Ordenanza es el de preservar el espacio público como un lugar de convivencia y civismo, en el que todas las personas puedan desarrollar en libertad sus actividades de libre circulación, de ocio, de encuentro y de recreo, con pleno respeto a la dignidad y a los derechos de los demás y a la pluralidad de expresiones y de formas de vida diversas existentes en Granada. Se suma, pues, y en algunos aspectos actualiza y mejora, a las previsiones ya contenidas en otras ordenanzas actualmente vigentes, y que se refieren también, de una manera u otra, y desde diversas vertientes, al complejo fenómeno de la convivencia, como por ejemplo, y entre otras, la Ordenanza reguladora de determinadas actividades de ocio en el término municipal de Granada, Ordenanza municipal de limpieza, ornato público y gestión de residuos urbanos ${ }^{61}$.

Si observamos la Ordenanza Municipal del Ayuntamiento de Barcelona, nos daremos cuenta de que existe una identificación casi absoluta entre ambas, la argumentación que nos brinda el Ayuntamiento de Granada para justificar el desarrollo y puesta en marcha de su ordenanza, es la misma que encontramos en la ordenanza barcelonesa ${ }^{62}$. Únicamente existe una ligera diferencia, en cuanto que la ordenanza que analizamos en este momento, añade a su texto otra serie de conductas que hacen referencia al cuidado del medio ambiente, como son la contaminación, bien sea acústica, atmosférica o de aguas, entre otras, y la tenencia de animales, con el fin de asegurar el bienestar y los cuidados necesarios para con ellos.

Partiendo de este paralelismo y casi idéntico desarrollo, continuamos manifestando que esta Ordenanza pretende ser una

nanza de medidas para fomentar y garantizar la convivencia ciudadana en el espacio Público de Granada, cuyo texto fue aprobado inicialmente por acuerdo plenario de 29 de mayo de 2009 , y una vez resueltas las alegaciones presentadas durante el periodo de información pública.

61 Véase, la exposición de motivos, primer párrafo, de la Ordenanza de medidas para fomentar la convivencia ciudadana en el espacio público.

62 Confróntese al respecto, GONZALEZ DEL RÍO, El ejercicio de la prostitución y el derecho del trabajo, 2013, p. 63. 
herramienta efectiva para hacer frente a las nuevas situaciones y circunstancias que pueden afectar a la convivencia o alterarla. Manteniendo una respuesta democrática y equilibrada ante estas nuevas situaciones, todo ello, reconociendo el derecho de todos a comportarse libremente en los espacios públicos y a ser respetados en su libertad, así como, manifestando la necesidad de que todos asumamos determinados deberes de convivencia y de respeto a la libertad, la dignidad y los derechos reconocidos a los demás, y mantenimiento del espacio público en condiciones adecuadas. Todo ello, además, siendo conscientes de que, para el logro de estos objetivos, no basta con el ejercicio, por parte de la autoridad municipal, de la potestad sancionadora, que en ocasiones también es necesario, sino que es preciso, también, que el Ayuntamiento lleve a cabo las correspondientes actividades de fomento y de prestación social necesarias para promover los valores de convivencia y el civismo en la ciudad y para atender convenientemente a las personas que lo puedan necesitar ${ }^{63}$.

Esta Ordenanza actúa dentro del ámbito de competencias de que dispone el Ayuntamiento de Granada con el fin de evitar todas las conductas que puedan perturbar la convivencia y minimizar los comportamientos incívicos que se puedan realizar en el espacio público. Tiene, así pues, una naturaleza claramente transversal, al afectar a un buen número de competencias locales y atravesar literalmente gran parte de la estructura de responsabilidades políticas y del sistema administrativo municipal. También prevé mecanismos para impedir la explotación de las personas mediante la prostitución; evita que el ejercicio de la prostitución en la calle afecte a la convivencia ciudadana, y establece al mismo tiempo medidas sociales como el Programa para ordenación del Trabajo Sexual y la Agencia, que deben dar salida a la situación actual ${ }^{64}$.

63 Véase la Exposición de motivos, segundo párrafo, de la Ordenanza de medidas para fomentar la convivencia ciudadana en el espacio público.

64 Según lo establecido en la Exposición de motivos, tercer párrafo, de la Ordenanza de medidas para fomentar la convivencia ciudadana en el espacio público. 
Si bien el texto de la citada ordenanza es similar, casi en su integridad, al texto de la ordenanza catalana, presenta algunos aspectos distintos. En este sentido, entre otras muchas conductas, el Título III, se divide en seis capítulos, y se encarga de regular la protección del entorno urbano desde cuatro grandes perspectivas medioambientales, como son las contaminaciones atmosférica, acústica, por residuos y la lumínica. Así mismo establece un régimen sancionador para los infractores.

En lo que a las normas de conductas que quedan prohibidas por dicha Ordenanza respecta, el Título II recoge una amplia lista todas aquellas que puedan afectar la convivencia ciudadana y el civismo. Las primeras conductas entendidas como prohibidas por vulnerar el fundamento y el objeto de este texto, son aquellas que atentan contra la dignidad de las personas ${ }^{65}$, reguladas con el fin de evitar en el espacio público todas las prácticas individuales o colectivas que atenten contra la dignidad de las personas, así como las prácticas discriminatorias de contenido xenófobo, racista, sexista, homófobo, o de cualquier otra condición o circunstancia personal, económica o social, especialmente cuando se dirijan a los colectivos más vulnerables. A continuación, en el capítulo II, regula aquellas conductas que puedan degradar la visión del entorno urbano, que se fundamentan en el derecho a disfrutar del paisaje urbano de la ciudad, que es indisociable del correlativo deber de mantenerlo en condiciones de limpieza, pulcritud y decoro ${ }^{66}$. Así, continúa recopilando distintas conductas que en definitiva resultarían inadecuadas para el buen uso del espacio público, como el consumo de bebidas alcohólicas; hacer las necesidades fisiológicas; actitudes vandálicas en el uso del mobiliario urbano; o actividades y prestación de servicios no autorizados, entre otras. Llegados al capítulo V, nos encontramos con otras conductas en el espacio público como aquellas que adoptan formas de mendicidad o la utilización del

65 Capítulo I, artículo 30 de la Ordenanza de medidas para fomentar la convivencia ciudadana en el espacio público.

66 Capítulo II, artículo 34.1 de la Ordenanza de medidas para fomentar la convivencia ciudadana en el espacio público. 
espacio público para el ofrecimiento y demanda de servicios sexuales, la cual analizaremos detenidamente.

Según lo establecido en el artículo 53, las conductas reguladas como infracción en esta sección persiguen preservar de la exhibición de prácticas sexuales y del ofrecimiento o demanda de servicios sexuales en la vía pública con la finalidad de mantener la pacífica convivencia del espacio público de la Ciudad de Granada, evitando problemas de vialidad en lugares de tránsito público, además de prevenir la explotación y trata de determinados colectivos.

Con esta normativa se establece una regulación sobre el uso y ocupación del espacio público como consecuencia de las prácticas sexuales y del ofrecimiento y demanda de servicios sexuales, y se dicta teniendo en cuenta las competencias municipales y los bienes jurídicos protegidos contemplados en el anterior párrafo ${ }^{67}$.

De acuerdo con lo establecido hasta el momento, y las finalidades perseguidas con esta regulación, las conductas, en este ámbito, que quedan prohibidas son, las prácticas sexuales, el ofrecimiento, solicitud, negociación y aceptación directa o indirectamente de servicios sexuales retribuidos en el espacio público de la ciudad de Granada, en todo su término municipal y de forma especial cuando excluyan o limiten la compatibilidad de los diferentes usos de dicho espacio público, conductas que tienen la consideración de leve ${ }^{68}$. Ahora bien, cuando estas mismas conductas se lleven a cabo en espacios situados a menos de doscientos metros de distancia de zonas residenciales, centros educativos o cualquier otro lugar donde se realice actividad comercial o empresarial alguna ${ }^{69}$, en este caso tendrán la consideración de muy graves ${ }^{70}$.

67 Al respecto véase, JIMÉNEZ BAUTISTA, Red de Revistas Cientificas de América Latina y El Caribe, España y Portugal, 2008, pp.380-398.

68 Artículo 55.3 de la Ordenanza de medidas para fomentar la convivencia ciudadana en el espacio público.

69 Artículo 54 de la Ordenanza de medidas para fomentar la convivencia ciudadana en el espacio público.

70 Artículo 55.3 de la Ordenanza de medidas para fomentar la convivencia ciudadana en el espacio público. 
De la redacción de este precepto podemos extraer varios puntos de análisis, en primer lugar, con respecto a la prohibición de prácticas sexuales en términos generales, la normativa no concreta en que han de consistir esas prácticas, permitiendo una interpretación amplia, que pudiera oscilar desde el simple contacto o roce con connotación sexual, hasta la consumación del acto sexual. En segundo lugar, la conducta de ofrecimiento de servicios sexuales retribuidos, implica la actuación de la persona que ejerce la prostitución, frente a la solicitud de los mismos que será atribuida evidentemente al cliente. De igual modo, no suscitan ningún problema los términos negociación y aceptación, que por supuesto implica a ambos sujetos en su comisión. No tan explicativo, son los términos directa o indirectamente, con respecto al modo en que se puedan llevar a cabo las conductas anteriores. Dejando un amplio margen interpretativo al respecto.

Con respecto al régimen sancionador, que prevé esta normativa para las conductas descritas anteriormente, en cuanto aquellas consistentes en prácticas sexuales, el ofrecimiento, solicitud, negociación y aceptación directa o indirectamente de servicios sexuales retribuidos en el espacio público, la Policía Local de Granada o los servicios municipales competentes, se limitarán inicialmente a recordar a las personas que incumplieran este precepto, que dichas prácticas están prohibidas por la presente Ordenanza. Si estas personas persistieran en su actitud, se procederá al inicio del correspondiente procedimiento administrativo sancionador y a toda aquella actuación que legalmente corresponda derivada de la identificación de dichas personas.

En todo caso, si estas conductas, constituyeran una infracción muy grave, y por consiguiente, se llevaran a cabo en espacios situados a menos de doscientos metros de distancia de zonas residenciales, centros educativos o cualquier otro lugar donde se realice actividad comercial o empresarial alguna, se informará a estas personas de que dichas conductas están prohibidas, así como de las posibilidades que las instituciones públicas 
y privadas les ofrecen de asistencia social, prestándoles, además la ayuda que sea necesaria ${ }^{71}$.

Sin embargo sin perjuicio de exigir, cuando proceda, las responsabilidades de carácter penal o civil correspondientes, y de los apercibimientos a que hubiera lugar, las infracciones a los preceptos de la presente Ordenanza serán sancionables en todo caso, así, las infracciones leves podrán ser sancionadas con 1 euros hasta 750 euros y las infracciones muy graves desde 1.501 a 3.000 euros.

Junto con el régimen sancionador la normativa regula una serie de posibles intervenciones sociales en este sentido. El Ayuntamiento de Granada, a través de los servicios sociales competentes, prestará información y ayuda a todas aquellas personas que ejerzan el trabajo sexual en la ciudad y en especial a aquellas que quieran abandonar su ejercicio. Los servicios municipales competentes, con el auxilio de los agentes de la autoridad, si es el caso, informarán a todas las personas que ofrecen servicios sexuales retribuidos, en espacios públicos de las dependencias municipales y de los centros de atención institucional o de carácter privado (asociaciones, $\mathrm{ONG}$, etc.) a los que podrán acudir para recibir el apoyo que sea necesario para abandonar esas prácticas. Otra de las medidas o intervenciones por parte del Ayuntamiento es la aprobación del Programa para Ordenación del Trabajo Sexual, a fin de evitar que el ofrecimiento de servicios sexuales en la vía pública afecte a la convivencia ciudadana y poder atender a las personas que realicen estas actividades.

El órgano creado al efecto para desarrollar el programa para Ordenación del Trabajo Sexual, coordinará todas las actuaciones de servicios a las personas que realizan esta actividad en el espacio urbano, y en este sentido recogerá:

a) Colaborar y establecer convenios con entidades que trabajen con estos colectivos.

71 Artículos 55.1 y 55.2 de la Ordenanza de medidas para fomentar la convivencia ciudadana en el espacio público. 
b) Informar sobre los servicios públicos disponibles y muy especialmente los servicios a las personas, como servicios sociales, servicios educativos y servicios sanitarios.

c) Informar de los derechos fundamentales de estas personas.

d) Colaborar con las entidades referentes a esta materia para ofrecer nueva formación a las personas que integran este colectivo.

e) Informar y ofrecer los recursos laborales disponibles desde la Administración o en colaboración con las entidades referentes en la materia.

\section{Ordenanzas municipales abolicionistas}

Hasta aquí hemos analizado el contenido de algunas de esas ordenanzas que en aras de una protección ciudadana, del buen mantenimiento del espacio público y de las condiciones de civismo, han prohibido el ejercicio de la prostitución en las calles de sus respectivas ciudades, sancionando para ello, tanto a la persona ejerciente de esta actividad como al cliente de la misma, y en consecuencia, como apuntábamos responden a un modelo de ordenanzas de corte prohibicionista. A continuación, analizaremos aquellas normativas que si bien, identifican el ejercicio de la prostitución con un acto contrario al buen uso del espacio público en condiciones de civismo, han optado por no sancionar a aquel que ejerce la actividad, y únicamente desplegar su función sancionadora con aquellos que soliciten prestaciones sexuales remuneradas, es decir, el cliente.

\subsection{Ayuntamiento de Sevilla}

El Ayuntamiento de Sevilla, aprobó en enero de 2011, la Ordenanza para luchar contra la prostitución y la trata con fines de explotación sexual en dicha ciudad ${ }^{72}$.

72 Aprobada en enero de 2011 en Junta extraordinaria de Gobierno y refrendada definitivamente en el Pleno ordinario del 28 de enero del mismo año. 
El objetivo principal de esta Ordenanza es el de luchar contra la prostitución y la trata con fines de explotación sexual en la ciudad de Sevilla, preservando los espacios públicos como lugares de convivencia, civismo e igualdad, evitando actividades de explotación sexual que difunden una imagen del ser humano, muy especialmente de la mujer, como mero objeto sexual y perturban la convivencia social. Para ello se establecen mecanismos para impedir en los espacios públicos la explotación de las personas mediante la prostitución por entender que además de difundir una imagen de la mujer como mero objeto sexual, perturba a la convivencia ciudadana; asimismo se refuerzan los controles a los locales donde presuntamente se producen situaciones de explotación y se recogen medidas para evitar la publicidad sexista, relativa a la explotación sexual y/o a la prostitución ${ }^{73}$.

Según lo dispuesto en la exposición de motivos IV, esta Ordenanza entiende que la mujer en situación de prostitución ha de tener la consideración de víctima, ya que afirma que la prostitución es una forma extrema de violencia de género. Y es en este contexto donde hay que considerar como beneficiarios de la explotación sexual tanto al proxeneta como al cliente. Continúa manifestando que no se puede ni se debe dar el mismo tratamiento a la víctima y al explotador. Es por ello que esta normativa sanciona la demanda de servicios sexuales, favorecimiento, promoción o facilitación de estas conductas, y nunca el ofrecimiento por parte de la víctima, a diferencia de las otras ordenanzas que ya hemos analizado ${ }^{74}$. Lo que la convierte en una ordenanza de corte claramente abolicionista ${ }^{75}$. Esta Ordenanza

73 Véase, la Exposición de motivos de la Ordenanza Municipal para luchar contra la prostitución y la trata con fines de explotación sexual.

$74 \mathrm{Al}$ respecto véase, GONZALEZ DEL RÍO, El ejercicio de la prostitución y el derecho del trabajo, 2013, p. 64.

75 En este sentido, según VILLACAMPA ESTIARTE, "a diferencia del modelo representado por la ordenanza cívica de Barcelona, la ordenanza sevillana, en el marco del Primer Plan de Acción Integral para promover la erradicación de la trata, la prostitución y otras formas de explotación sexual, que había sido aprobado en el referido ayuntamiento ya en el año 2009, par- 
pretende proteger el adecuado uso de la vía pública abriendo una nueva vía de sanciones a uno de los elementos necesarios para la existencia de la prostitución, que aparece, hasta ahora, como elemento sin responsabilidad, este elemento es el cliente.

Para lograr los objetivos que anteriormente expusimos, este texto regula una serie de medidas encaminadas específicamente al fomento y a la promoción de la igualdad entre hombres y mujeres; identifica los bienes jurídicos protegidos; prevé medidas para fomentar la igualdad, detalla cuales son las normas de conducta que se prohíben, y la sanción que corresponde por perturbar o lesionar la convivencia ciudadana (artículo 1.2).

Es importante destacar, para comenzar, los principios inspiradores de las mismas. En primer lugar, encontramos el principio de igualdad de trato, según él, se prohíbe toda discriminación basada en el sexo de las personas, tanto directa como indirecta y cualquiera que sea la forma utilizada para ello. No obstante, no se considerarán constitutivas de discriminación por razón de sexo aquellas medidas que, aunque supongan un tratamiento diferente para las mujeres y para los hombres, tienen una justificación objetiva y razonable, entre las que se incluyen las acciones positivas para las mujeres, al tratarse de un grupo de población que requiere un plus de protección por los condicionamientos económicos y sociales que condicionan su situación y la violencia de género ejercida sobre ellas. Por consiguiente se deben adoptar medidas que garanticen el efectivo ejercicio de hombres y mujeres, en condiciones de igualdad, de los derechos sociales, económicos, políticos, civiles, culturales y demás reconocidos tanto en la Constitución como en el resto de de nuestro ordenamiento jurídico ${ }^{76}$. Deben establecerse los medios

te claramente de los postulados abolicionistas.[...] Identifica los conceptos de prostitución y trata, conforme a los postulados abolicionistas y, partiendo de la consideración de las mujeres en situación de prostitución como víctimas de una forma extrema de violencia de género, las considera víctimas", REPC, 2015, p. 431.

76 Véanse los artículos 6 y 7 de la Ordenanza para luchar contra la prostitución y la trata con fines de explotación sexual. 
necesarios para que la consecución de la igualdad entre hombres y mujeres y la erradicación de la violencia de género se realice respetando tanto la diversidad y las diferencias existentes entre mujeres y hombres en cuanto a su biología, condiciones de vida, aspiraciones y necesidades, como a la diversidad y diferencias existentes entre los distintos grupos de mujeres (artículo 8).

Esta Ordenanza incorpora la perspectiva de género de manera que tiende a eliminar las desigualdades y promover la igualdad de mujeres y hombres, teniendo en cuenta las diferentes situaciones, condiciones, aspiraciones y necesidades de mujeres en condición de explotación sexual. En consecuencia para lograrlo, asegura que se debe promover la eliminación de los roles sociales y estereotipos en función del sexo sobre los que se asienta la desigualdad y la violencia ejercida contra la mujer que tienden a tratar a éstas como un objeto de consumo, cosificando $\mathrm{y}$ atentando con los principios básicos de dignidad y respeto a las mismas ${ }^{77}$.

Para lograr dichos objetivos, en su capítulo primero, título I, regula las normas de conducta en el espacio público que suponen un atentado contra la dignidad de las personas en situación de explotación sexual. Más específicamente, en el artículo 14 de la respectiva Ordenanza, se recogen las normas de conductas que están prohibidas, las cuales son:

Solicitar, negociar o aceptar, directa o indirectamente, servicios sexuales retribuidos en los espacios y/o lugares descritos en el artículo $4^{78}$ de la presente Ordenanza considerando que estas conductas, en cualquier caso, son incompatibles con los usos atribuidos a los mismos.

Ahora bien, ¿en qué consisten exactamente estas conductas?, pues tal y como pone de manifiesto la propia Ordenanza, a estos efectos se considerará que hablamos de solicitud, demanda

77 Artículos 9 y 11 de la Ordenanza para luchar contra la prostitución y la trata con fines de explotación sexual.

78 Artículo 4: Ámbito de aplicación objetiva, de la Ordenanza para luchar contra la prostitución y la trata con fines de explotación sexual. 
o aceptación de servicios sexuales a cambio de un pago, tanto si la proposición que el solicitante haga es para su propio disfrute, como si es para el de una tercera persona. En definitiva lo que se sanciona es la acción de proponer a una persona mantener relaciones sexuales a cambio de una remuneración, que no se especifica en ningún caso si debe ser económica o en especies.

Otra de las conductas que de igual modo se prohíbe, es mantener relaciones sexuales mediante retribución en el espacio público.

Y finalmente, se prohíben las conductas que puedan considerarse como favorecedoras o que promuevan el consumo de prostitución u otras formas de explotación sexual, con independencia de que sean constitutivas de infracción penal conforme a nuestro ordenamiento jurídico. A estos efectos, el texto, como sucede en otras ordenanzas, considera dentro de estas conductas de favorecimiento las consistentes en acercar a los clientes a donde se encuentran las personas en situación de prostitución, y cualquier otra que sirva para el acercamiento entre ambas partes.

Por su parte, a diferencia de otras normativas municipales, ésta determina qué actuaciones se consideran promoción o que promueven el consumo de la prostitución. De esta forma, considera como tal, el uso de cualquier medio para contactar a los clientes con personas en situación de prostitución, como pudieran ser los panfletos, carteles, anuncios u otros medios para cuya difusión se utilicen cualquiera de los elementos descritos en el artículo 4 de esta Ordenanza ${ }^{79}$.

Un aspecto muy importante que se refleja en esta Ordenanza, y que la distingue de otras muchas es que todo lo expuesto anteriormente, es decir, las conductas infractoras, en ningún caso podrán estar referidas a las personas que ejercen la prostitución, a efectos sancionadores. Como ya anunciábamos al comienzo de este análisis, cuando describíamos los argumentos plasmados en la exposición de motivos de la citada normativa,

79 Consultar, el artículo 14 de la de la Ordenanza para luchar contra la prostitución y la trata con fines de explotación sexual. 
las conductas serán sancionables en el supuesto de ser cometidas por clientes o explotadores, en ningún caso si se realizasen por la persona prostituta, o lo que es lo mismo, la víctima.

En cuanto al régimen sancionador ${ }^{80}$, las infracciones consideradas como graves, serán sancionadas con multa de 750,01 a 1.500 euros, las infracciones muy graves, serán sancionadas con multa de $1.500,01$ a 3.000 euros, siempre y cuando se lleven a cabo en espacios situados a menos de doscientos metros de distancia de centros docentes o educativos u otros espacios con afluencia de público infantil y/o juvenil; en lugares o alrededores de los mismos, al menos doscientos metros, con gran afluencia de público como puede ser cualquier acto público de naturaleza cultural, festiva, lúdica o deportiva, o de cualquier otra índole; o en lugares que impliquen una mayor vulnerabilidad para las personas en situación de prostitución y/o explotación sexual por su aislamiento, escasez de alumbrado, cercanía a vías de circulación de vehículos y espacios que impidan la huida. Si estas conductas fueran realizadas por un grupo de personas, se imputará la comisión de la infracción a todos los miembros del mismo que resulten identificados en el lugar de los hechos y evidentemente hubieran participado en la conducta que se sancione en cada caso ${ }^{81}$.

El Ayuntamiento sevillano, ha introducido en el texto de su Ordenanza, a diferencia de otras, de corte abolicionista, junto con las conductas descritas anteriormente y que atenta contra la dignidad de la persona prostituta, un grupo de conductas que si bien, en la práctica persiguen la misma finalidad que las otras, son nombradas de manera distinta, como medidas contra la publicidad sexista, recogidas en el capítulo segundo del título I. Las normas de conductas ${ }^{82}$ que en este sentido están o quedan prohibidas son, la colocación, reparto, divulgación y/o difusión

80 Al respecto véase, CARRETERO, Biblioteca Digital de la UNED, p. 1. (Consultar http://www.uned.es/ca-tortosa/Biblioteca_Digital/Biblio/Carmen_Carretero/Espana.pdf, última visita el 07 de febrero de 2018).

81 Artículo 15 de la Ordenanza para luchar contra la prostitución y la trata con fines de explotación sexual.

82 Véase el artículo 17 de la Ordenanza para luchar contra la prostitución y la trata con fines de explotación sexual. 
de publicidad que promueva, favorezca o fomente el consumo de prostitución y la explotación sexual de las mujeres, el mercado prostitucional y el turismo sexual ${ }^{83}$. Concretamente cuando se utilice para ello, alguno o algunos de los elementos que conforme al artículo 4 de la presente Ordenanza constituyen el ámbito objetivo de aplicación de la misma; el estacionamiento o aparcamiento de vehículo o remolque o cualquier otro elemento, cuya función normal en el espacio público no sea de soporte publicitario conforme dispone el artículo $3,2^{\circ}$ apartado c) de la Ordenanza sobre publicidad de la ciudad de Sevilla ${ }^{84}$; o la publicidad móvil tal y como aparece descrita en el artículo 3, $1^{\mathrm{o}}$ apartado $\mathrm{k}$ ) de la Ordenanza sobre publicidad de la ciudad de Sevilla ${ }^{85}$.

83 Con anterioridad a la entrada en vigor de esta ordenanza, ya en septiembre de 2010 se hizo una campaña promovida desde la Delegación de la Mujer del Ayuntamiento de Sevilla bajo el lema "Entras como cliente, sales como cómplice". Con ello se trataba de concienciar a los posibles clientes que con su actuación se estaban convirtiendo en cooperadores necesarios en la existencia del negocio de la prostitución y advertía de los efectos negativos que ello generaba. En concreto, se desplegaron números carteles a lo largo de la ciudad, difundidos en los distintos soportes y medios en los que se presentaba la figura de un varón simulando ser la foto de un detenido con una placa en la que se podía leer "piensa con la cabeza". Al respecto consúltese, AYUNTAMIENTO DE SEVILLA, Plan de acción integral para promover la erradicación de la trata, la prostitución y otras formas de explotación sexual. Informe de acciones desarrolladas en diciembre de 2011, 2011. (Consultar http://www.sevilla.org/ayuntamiento/competencias-areas/ area-de-igualdad-juventud-y-relaciones-con-la-comunidad-universitaria/amujer/plan-integral-contra-la-prostitucion/informe-de-evaluacion-diciembre-2011, última visita el 20 de diciembre 2017.

84 Véase la Ordenanza sobre publicidad de la ciudad de Sevilla, "artículo 3, $2^{\circ}$ apartado "Publicidad prohibida", c) La publicidad que se efectúe mediante estacionamiento o aparcamiento de vehículo o remolque o sobre cualquier otro elemento, cuya función normal en el espacio público no sea de soporte publicitario". (Consultar http://www.sevilla.org/urbanismo/documentos/ pdf/normativa/09. OrdenanzaPublicidad.pdf, última visita el 28 de noviembre de 2017).

$85 \mathrm{Al}$ respecto véase, la Ordenanza sobre publicidad de la ciudad de Sevilla, "artículo 3, $1^{\circ}$ apartado "Publicidad excluida", k) La publicidad móvil, tanto la incorporada a un vehículo o a su remolque, sea terrestre o aérea, siempre que tales vehículos se hallen en los movimientos que le son propios. 
En lo que al régimen sancionador de estas conductas se refiere, el artículo 18 establece que tendrán la consideración de infracción leve y serán sancionadas con una multa de hasta 750 euros. Del mismo modo, cuando se tuviera conocimiento de la existencia de publicidad que se corresponda con las descripciones anteriores, se procederá a su retirada por parte de los servicios municipales competentes, con independencia de la resolución del procedimiento sancionador incoado ${ }^{86}$.

En cuanto a las medidas sociales que plantea esta Ordenanza, según lo recogido en el artículo 16 de la misma, el Ayuntamiento de Sevilla, a través de los servicios municipales competentes, prestará información y ayuda a todas aquellas personas que se encuentren en situación de prostitución y/o explotación sexual en la ciudad. De igual modo, los servicios municipales competentes, con el auxilio de los agentes de la autoridad si fuera necesario, informarán a todas las personas que se encuentren en situación de prostitución y/o explotación sexual de todos aquellos recursos sociales, cualquiera que sea la titularidad de los mismos, que trabajan con este colectivo y que posibilitan el abandono de esta situación. En aquellos casos especialmente graves o urgentes, es decir, cuando se haya producido daño a las personas en situación de prostitución y/o explotación sexual o exista riesgo evidente de que pueda producirse, y con el único objeto de que la persona pueda recibir efectivamente y lo antes posible la atención social y/o médica requerida, los agentes de la autoridad u otros servicios competentes podrán acompañarla a los recursos sociales mencionados en el apartado anterior. Además colaborará intensamente en la persecución y represión de las conductas atentatorias contra la libertad e indemnidad sexual de las personas que puedan cometerse en el espacio público, en

La terrestre precisará de autorización del Servicio Municipal de Tráfico y Transportes y la aérea del organismo competente conforme a la regulación vigente en la materia". (Consultar http://www.sevilla.org/urbanismo/documentos/pdf/normativa/09. OrdenanzaPublicidad.pdf. última visita el 28 de noviembre de 2017).

86 Artículo 19 de la Ordenanza la Ordenanza para luchar contra la prostitución y la trata con fines de explotación sexual. 
especial las actividades de proxenetismo o cualquier otra forma de explotación sexual, y muy especialmente, en los relativo a los/as menores.

En su lucha por erradicar la prostitución y cualquier otra forma de explotación sexual, el Ayuntamiento sevillano ha desarrollado múltiples proyectos que se suman a esta "Ordenanza para luchar contra la prostitución y la trata con fines de explotación sexual", y que reiteran la influencia abolicionista que ha seguido al respecto.

Ya en el año 2007 la Unidad contra la Violencia de Género de la Delegación de la Mujer realizó un informe sobre la situación de la prostitución y otras formas de explotación sexual en la ciudad de Sevilla así como sobre las opiniones de la ciudadanía al respecto. Entre los resultados del mismo se desprendieron dos conclusiones fundamentales: en primer lugar, que la prostitución se encuentra asociada a la pobreza, a situaciones de precariedad, y, en los últimos años, a la trata de mujeres con fines de explotación sexual; en segundo lugar, que causa daños psicológicos, vulnerabilidad, exclusión social y, con frecuencia, daños físicos en quienes la padecen. Al mismo tiempo en dicha investigación se evidenció que la ciudadanía también asocia la prostitución a mujeres en situaciones de precariedad y escasez de derechos, y por lo tanto, espera del Ayuntamiento que intervenga impulsando las medidas necesarias para erradicar la explotación sexual de las mujeres y menores.

Cumpliendo con este deseo de la ciudadanía, el Ayuntamiento de Sevilla se propuso el desarrollo del, ya mencionado Plan de Acción Integral para Promover la Erradicación de la Trata, la Prostitución y Otras Formas de Explotación Sexual en la ciudad ${ }^{87}$ con la intervención, de la Delegación de la Mujer y de todas aquella áreas que transversalmente son responsables de erradicar la violencia de género.

Para abordar este tema establece que se deberá intervenir conforme a una serie de principios rectores, en primer lugar, la protección de los y las menores es uno de los principios de 
nuestro ordenamiento jurídico, tanto nacional como autonómico, y teniendo en cuenta que, según establece, las situaciones de explotación sexual suelen empezar antes de la mayoría de edad, el presente Plan se va a inspirar en el mismo. Además considera que la mayoría de las personas en situación de prostitución, así como las víctimas de trata con fines de explotación son mujeres y niñas y que el perfil del "cliente-explotador" es mayoritariamente masculino.

Es por eso que afirma que no se sancionan a las mujeres prostituidas sino que se sigue en la intervención un enfoque de derechos humanos. Este Plan sanciona exclusivamente, en el marco de las competencias municipales, al prostituidor y al consumidor en espacio público de cualquier forma de explotación sexual, pues entiende que su conducta no tiene justificación alguna, promueve una imagen denigrante de los seres humanos, y es causa de problemas de convivencia e inseguridad.

Este Ayuntamiento es consciente de la enorme dificultad que conlleva abordar esta problemática, y de la diversidad de posturas que existen sobre cómo debe llevarse a cabo, así como de que aún no se ha encontrado un modelo de intervención satisfactorio. No obstante por su parte se ha optado por un enfoque abolicionista al considerar que es el más apropiado para erradicar cualquier forma de explotación sexual y ofrecer a las víctimas alternativas que le permitan vivir con seguridad, libertad y dignidad $^{88}$.

El presente Plan pretende avanzar en la erradicación de la explotación sexual en el municipio de Sevilla, siendo un pilar

87 Véase al respecto, AYUNTAMIENTO DE SEVILLA, Plan de Acción Integral para Promover la Erradicación de la Trata, la Prostitución y Otras Formas de Explotación Sexual, 2010-2015. (Consultar http://www.sevilla. org/ayuntamiento/competencias-areas/area-de-igualdad-juventud-y-relaciones-con-la-comunidad-universitaria/a-mujer/plan-integral-contra-laprostitucion/plan-integral-contra-la-prostitucion.pdf; última visita el 29 de noviembre de 2017).

88 Consultar el apartado 4. Principios rectores, del "Plan de Acción Integral para Promover la Erradicación de la Trata, la Prostitución y Otras Formas de Explotación Sexual en nuestra ciudad". 
fundamental del mismo las medidas de apoyo y reinserción a favor de las víctimas. Para lograrlo es requerible una intervención integral y de corresponsabilidad que deberá ser desarrollada desde todas las áreas del ayuntamiento, y que consisten en:

- Difundir y tener a disposición de cualquier persona información sobre las causas y consecuencias de la explotación sexual, y los recursos para las víctimas o personas en riesgo.

- Remitir a las instituciones especializadas a las víctimas o personas en riesgo.

- Llevar a cabo acciones concretas de sensibilización, información y formación, en esta materia.

- Promover la igualdad y prevenir la violencia de género, especialmente, la trata con fines de explotación sexual, la prostitución y otras formas de explotación sexual, dentro de sus propias competencias y según la legislación vigente.

Junto con ello, deberá intervenir de manera más especifica por barrios, teniendo en cuenta que la trata, la prostitución y otras formas de explotación sexual no inciden de la misma manera en todos los barrios y que, además, las zonas de mayor incidencia o problemática van cambiando, por lo tanto la intervención del Ayuntamiento se ajustará a las necesidades específicas por barrios en cada momento.

Además de estas intervenciones que podrían entenderse como básicas, deberá desarrollarse una intervención específica por parte de las Delegaciones de Economía y Empleo, Convivencia y Seguridad y, Salud, que consistirá en preparar un servicio específico para la detección, atención y remisión a los servicios especializados, dentro de sus programas y actividades, de las personas en situación de trata, prostitución o explotación sexual, o en riesgo de serlo, así como de las víctimas indirectas; teniendo en cuenta las peculiaridades y necesidades que se deriven de su origen, raza, cultura, pertenencia a minorías, discapacidades, enfermedades y/o adicciones, y cualquier otra 
relevante. Finalmente se regula una intervención para la atención especializada a las víctimas, personas en riesgo o víctimas indirectas, será aquella que, además de la básica y específica, deberá ser desarrollada por las Delegaciones de la Mujer, Bienestar Social, Cooperación al Desarrollo, y Convivencia y Seguridad, y que consiste en:

- Dar asistencia especializada e integral atendiendo a las circunstancias específicas de las propias víctimas directas e indirectas, así como personas en riesgo de serlo; teniendo en cuenta las peculiaridades y necesidades que se deriven de su origen, raza, pertenencia a minorías, discapacidades, enfermedades y/o adicciones y cualquier otra relevante.

- Fomentar y garantizar el ejercicio de los derechos por parte de las víctimas directas e indirectas, incluso la persecución de los delitos comunes (robo, agresiones físicas, agresiones sexuales, vejaciones...) o específicos (tráfico ilegal, detención ilegal, proxenetismo...) que hayan podido sufrir ${ }^{89}$.

Este Plan se estructura o contiene cinco áreas, las cuales recogen distintas acciones y objetivos.

La primera área recoge las medidas de sensibilización, prevención e investigación. El principal objetivo es investigar en profundidad la situación de la trata, prostitución y otras formas de explotación sexual en el municipio de Sevilla, así como la manera en la que se puede mejorar la intervención integral y multicompetencial. Se trata de sensibilizar respecto de esta problemática tanto a la población en general como al alumnado y al sector empresarial; potenciar la detección precoz de situaciones de explotación sexual o riesgo desde instituciones y programas del Ayuntamiento; y sensibilizar e informar a las asociaciones e instituciones de un modo continuo y constante.

89 Véase apartado 4, Principios rectores, del "Plan de Acción Integral para Promover la Erradicación de la Trata, la Prostitución y Otras Formas de Explotación Sexual en nuestra ciudad". 
La segunda área hace referencia a las medidas de formación y ámbito educativo. En este sentido el objetivo principal es mejorar la formación del personal funcionario y laboral del Ayuntamiento de Sevilla para garantizar una intervención de su actividad profesional conforme a los principios y directrices de este Plan. Los agentes sociales, que por su labor profesional o social intervengan en esta materia, así como los y las profesionales de los medios de comunicación, son otros sectores implicados así como la incorporación de medidas en el ámbito educativo.

El área tercera, regula las medidas de asistencia integral y protección a las víctimas, o personas en riesgo. Se crearan programas específicos para la atención integral y protección de las víctimas y personas en riesgo, teniendo en cuenta sus diversas circunstancias y necesidades, adaptando los programas y recursos preexistentes a esos objetivos. Además se activaran mecanismos que faciliten el acceso a esos programas y recursos de manera inmediata.

Las medidas normativas y sancionadoras del Ayuntamiento, reguladas en el área cuarta, recogen como objetivos la adaptación de las normas municipales a los objetivos del Plan, así como, impulsar la adopción de medidas contra los establecimientos que se dediquen a temas relacionados con la explotación sexual.

Y finalmente encontramos la quinta área, sobre medidas de reorganización, fortalecimiento, coordinación y cooperación. Consciente de que el fenómeno de la trata con fines de explotación sexual, la prostitución y otras formas de explotación sexual, deben ser abordados por diversos profesionales y desde la totalidad de las Delegaciones, fortalecerá en esta área la coordinación entre profesionales, y todos sus servicios, procediendo a la reorganización de los mismos para que cumplan los objetivos de este Plan. También incluirá en estas medidas a las entidades que trabajan con las víctimas o personas en riesgo, así como la cooperación al desarrollo ${ }^{90}$.

90 Véase el apartado 5, Proceso de elaboración del Plan: descripción, ámbito temporal y evaluación, del "Plan de Acción Integral para Promover la Erra-

Estudoos Penales y Criminológicos, vol. XXXIX (2019). ISSN 1137-7550: 217-301 -266- hitp://dx.doi.org/10.15304/epc.39.5330 


\subsection{Ayuntamiento de Valencia}

Por su parte, el ayuntamiento valenciano, aprobó en julio de 2013, la Ordenanza Municipal sobre el ejercicio de la prostitución en la vía pública ${ }^{91}$.

Este municipio, según pone de manifiesto la exposición de motivos de la citada Ordenanza, viene sufriendo la proliferación de distintas actividades lucrativas que afectan a la tranquilidad y seguridad de los ciudadanos y ciudadanas. Estas actividades tienen lugar en la vía pública y su ejercicio por unos cuantos restringe su uso para el resto de ciudadanos y ciudadanas, al perturbar la paz ciudadana mediante su utilización abusiva, afectando al ejercicio de los derechos legítimos de otras personas, al normal desarrollo de actividades y a la salubridad pública. Entre estas actividades destaca el ejercicio de la prostitución en determinadas zonas de la ciudad que acarrea problemas de convivencia ciudadana, afectan al orden público y a la imagen de la ciudad.

El fundamento de la presente Ordenanza es por tanto, que los ciudadanos y las ciudadanas puedan hacer uso de los espacios públicos sin las limitaciones y/o exclusiones que el ejercicio de la prostitución en la vía pública provoca, así como, proteger a los menores de edad alejando de cualquier parque infantil o centro de estudios, cualquier conducta relacionada con el mundo de la prostitución. En resumen lo que se busca con este texto es luchar contra la prostitución preservando los espacios públicos como lugares de convivencia, civismo e igualdad, evitando actividades de explotación sexual que difunden una imagen del ser humano, muy especialmente de la mujer, como mero objeto sexual y que además perturban la convivencia social.

El artículo 1 de la citada ordenanza vuelve a recoger tanto el fundamento como el objetivo que se persigue con la misma.

dicación de la Trata, la Prostitución y Otras Formas de Explotación Sexual en nuestra ciudad".

91 Aprobada por acuerdo plenario de fecha: 26.07.2013. Fecha de publicación en el BOP: 12.08.2013. 
Como preservar a los menores de la exhibición de prácticas de ofrecimiento o solicitud de servicios sexuales en espacios de dominio público, mantener la convivencia, garantizar el libre acceso de los ciudadanos a los espacios públicos y prevenir la explotación de determinados colectivos. Por lo que respecta al objetivo perseguido, éste, es establecer una regulación sobre la ocupación del espacio público como consecuencia de las actividades de ofrecimiento y demanda de servicios sexuales y se redacta teniendo en cuenta los títulos competenciales municipales y los bienes jurídicos protegidos contemplados en el párrafo anterior. También se regula la utilización de los soportes publicitarios en el término municipal de Valencia para la promoción de servicios sexuales ${ }^{92}$.

Para asegurarse su objetivo y establecer una regulación sobre la ocupación del espacio público, en esta Ordenanza se recogen una serie de normas de conductas que quedan prohibidas en todo el territorio valenciano y que podrán ser sancionadas por afectar la convivencia en el espacio público. De esta forma en su artículo 2, establece que queda prohibido, ofrecer, solicitar, negociar y/o aceptar, directa o indirectamente, servicios sexuales retribuidos, cuando estas prácticas supongan excluir o limitar la compatibilidad de los diferentes usos del espacio público.

De igual modo se prohíben todas estas conductas cuando se realicen en espacios públicos situados a menos de doscientos metros de distancia de centros docentes o educativos en los que se imparten enseñanzas del régimen general del sistema educativo, así como de parques infantiles.

Otra de las conductas que se prohíben en virtud de esta Ordenanza es mantener relaciones sexuales retribuidas en el espacio público, no obstante, en este sentido, esta normativa introduce una novedad con respecto de otras ordenanzas, y es que añade que el hecho me mantener relaciones sexuales en el espacio público serán sancionadas aún cuando éstas tengan lugar en el interior de un vehículo.

92 Véase el artículo 1 de la Ordenanza Municipal sobre el ejercicio de la prostitución en la vía pública. 
Nuevamente añade una serie de conductas que hasta el momento no aparecen en el resto de ordenanzas que hemos analizado, como son las conductas, que bajo la apariencia de prostitución, obstaculicen o impidan el libre tránsito de los ciudadanos por los espacios públicos coaccionando y/o acosando a los viandantes. En este sentido, la normativa no determina de ningún modo que debe entenderse por conductas bajo la apariencia de prostitución, dejando un margen discrecional a las sanciones de conductas que deberán ser interpretadas por los órganos sancionadores, y que según su opinión y criterio aparenten ser conductas de prostitución que obstaculizan el libre tránsito de ciudadanos por el espacio público.

Finalmente prohíbe la promoción de servicios sexuales en todos los soportes publicitarios existentes en el término municipal de Valencia, bien sean de titularidad pública o privada, así como en todos los medios de transporte urbano.

Una vez expuestas las conductas que a tenor de esta Ordenanza están totalmente prohibidas y sujetas a sanción, debe determinar quiénes son los sujetos responsables, o a quienes se castiga. Como ya hemos estudiado, y atendiendo a su naturaleza abolicionista, esta normativa sanciona al cliente que acude al reclamo y a los intermediarios y/o proxenetas que explotan a las mujeres que ejercen la prostitución. Es decir, en esta normativa ninguna de las conductas descritas estarán referidas a las personas en situación de prostitución, a efectos sancionadores ${ }^{93}$. Aunque en este caso, cabe reflexionar sobre algunos términos que podrían ser dados a la confusión, estamos hablando concretamente del término "ofrecer", en cuanto a conducta que queda prohibida a tenor de la presente ordenanza. Este término, en consonancia con los servicios sexuales, es evidente que hace referencia al sujeto activo que ofrece tales servicios, o lo que es lo mismo la persona que ejerce la prostitución, por lo tanto el sujeto infractor en este caso sería el trabajador sexual, lo que

93 Artículo 3.2 de la Ordenanza Municipal sobre el ejercicio de la prostitución en la vía pública. 
resulta contradictorio con lo establecido en el artículo 3.2 que como hemos dicho excluye del ámbito del régimen sancionador a las personas en situación de prostitución ${ }^{94}$.

En cuanto al régimen de las sanciones, esta Ordenanza Municipal describe detalladamente, en el artículo 3, todas las conductas que se engloban en una infracción leve, grave y muy grave.

De ese modo, se entenderán como infracciones muy graves, en primer lugar, ofrecer, solicitar, negociar y/o aceptar, directa o indirectamente, servicios sexuales retribuidos en el espacio público situados a menos de doscientos metros de distancia de centros docentes o educativos en los que se imparten enseñanzas del régimen general del sistema educativo así como de parques infantiles. En lugares que impliquen una mayor vulnerabilidad para las personas en situación de prostitución y/o explotación sexual por su aislamiento, escasez de alumbrado, cercanía a vías de circulación de vehículos y espacios que impidan la huida. En segundo lugar, la realización de servicios sexuales retribuidos en el espacio público, aunque sea en el interior de un vehículo situados a menos de doscientos metros de distancia de centros docentes o educativos en los que se imparten enseñanzas del régimen general del sistema educativo así como de parques infantiles. También en lugares que impliquen una mayor vulnerabilidad para las personas en situación de prostitución y/o explotación sexual por su aislamiento, escasez de alumbrado, cercanía a vías de circulación de vehículos y espacios que impidan la huida. Y por último, la promoción de servicios sexuales en soportes publicitarios instalados a menos de doscientos metros de centros docentes o educativos en los que se imparten enseñanzas del régimen general del sistema educativo, así

94 En este sentido, como asegura VILLACAMPA ESTIARTE, “...pese a que esta norma afirma que sanciona a los clientes y a quienes facilitan la prostitución, lo cierto es que termina sancionando a las mismas trabajadoras sexuales exactamente en los mismos términos que a quienes consumen sus servicios.", REPC, 2015, p. 432. 
como de parques infantiles. Cuando se tenga conocimiento de la existencia de la publicidad descrita en la presente Ordenanza se procederá a la inmediata retirada de la misma por los servicios municipales competentes, independientemente de la resolución del procedimiento sancionador incoado. Dichas infracciones serán sancionadas con una pena de multa de entre 1.001 a 2.000 euros (artículo 4).

Las infracciones graves por su parte, consistirán en ofrecer, solicitar, negociar y/o aceptar, directa o indirectamente, servicios sexuales retribuidos en el espacio público, cuando estas prácticas supongan excluir la compatibilidad de los diferentes usos del espacio público. La realización de servicios sexuales retribuidos en el espacio público, aunque sea en el interior de vehículos y la promoción de servicios sexuales en soportes publicitarios instalados en el término municipal de Valencia. Estas infracciones se sancionarán con multas de entre 301 a 1.000 euros (artículo 4).

En cuanto a las infracciones leves, la Ordenanza regula como tales, ofrecer, solicitar, negociar y/o aceptar, directa o indirectamente, servicios sexuales retribuidos en el espacio público, cuando estas prácticas supongan limitar la compatibilidad de los diferentes usos del espacio público. Obstaculizar o impedir el libre tránsito de los ciudadanos y las ciudadanas por los espacios públicos coaccionando y/o acosando a los viandantes. Estas infracciones serán sancionadas con multas de hasta 300 euros (artículo 4).

No obstante, sin perjuicio de la aplicación de la sanciones citadas anteriormente, además los Agentes de la Autoridad requerirán a los presuntos infractores para que cesen en su conducta, advirtiéndoles de que las mismas están prohibidas y de que, de persistir en su actitud, además de denunciar su conducta podrían incurrir en la infracción de desobediencia a Agentes de la Autoridad, para tal fin levantarán acta haciendo constar los datos de los requeridos, así como las circunstancias de lugar, fecha, hora y demás detalles de interés relacionados con los hechos. Si 
tras ser requeridos, los Agentes observaran a las personas requeridas realizando alguna de las conductas prohibidas, el Agente procederá a denunciar al presunto infractor (artículo 5.1 y 5.2).

Finalmente con respecto a las medidas sociales el texto hace referencia a las intervenciones específicas en esta materia por parte del ayuntamiento. Según estas intervenciones el ayuntamiento a través de la figura de los servicios sociales deberá informar y ayudar a todas las personas que ejercen el trabajo sexual en el término municipal y que quieran abandonar su ejercicio. Más concretamente los servicios municipales competentes y los agentes de autoridad, en su caso, informarán a todas las personas que ofrecen servicios sexuales retribuidos en espacios públicos de las dependencias municipales y de los centros de atención institucional o de carácter privado, como asociaciones u ONG, entre otros, a los que podrían acudir para recibir el apoyo que sea necesario para abandonar esas prácticas. A su vez, colaborará en la persecución y represión de las conductas atentatorias contra la libertad sexual de las personas que puedan cometerse en el espacio público, en especial las actividades de proxenetismo o cualquier otra forma de explotación sexual muy especialmente en lo relativo a menores ${ }^{95}$.

\subsection{Ayuntamiento de Madrid}

La preocupación municipal por las materias vinculadas a la convivencia y al civismo también ha estado presente en la ciudad de Madrid, por ello, el Ayuntamiento madrileño, por acuerdo plenario de 26 de septiembre de 2012, acordó elaborar una Ordenanza de Convivencia Ciudadana de la Ciudad de Madrid, dicha ordenanza finalmente se aprobó al inicio de $2014^{96}$.

El objetivo principal que persigue esta Ordenanza del Ayuntamiento de Madrid, es el de preservar el espacio público como lugar de convivencia y civismo, en el que todas las perso-

95 Véase el artículo 5.3, 5.4 y 5.5 respectivamente, de la Ordenanza Municipal sobre el ejercicio de la prostitución en la vía pública.

96 Aprobada por acuerdo plenario en enero de 2014. 
nas puedan desarrollar en libertad sus actividades de libre circulación, ocio, encuentro y recreo, con pleno respeto a la dignidad y a los derechos de los demás y a la pluralidad de expresiones y de formas de vida diversas existentes, y a la vez, que constituya una herramienta eficaz para que los servicios municipales puedan asegurar el libre ejercicio de los derechos de todos los ciudadanos y promover la convivencia y la protección del espacio público ante conductas irresponsables o antisociales ${ }^{97}$.

Ésta, intenta ser una respuesta democrática y equilibrada para hacer frente a las situaciones y circunstancias que puedan afectar o alterar la convivencia ciudadana. Se fundamenta en el reconocimiento del derecho de todos a comportarse libremente en el espacio público y a ser respetados en su libertad; pero partiendo de la necesidad de que todos asumamos determinados deberes de convivencia y de respeto a la libertad, la dignidad y los derechos reconocidos a los demás, así como el mantenimiento del espacio público en condiciones adecuadas. De esta manera, las conductas individuales solo se tipifican como infracciones en la medida en que afecten o impidan el libre ejercicio de las demás personas.

Siendo conscientes de que, para el logro de estos objetivos, no basta tan solo con el ejercicio de la potestad sancionadora, el Ayuntamiento de Madrid asume el principio de prevención, dando prioridad a todas aquellas medidas municipales encaminadas a evitar riesgos para la convivencia ciudadana y el civismo en el espacio público mediante la adopción de las medidas sociales para atender a los grupos más vulnerables, como personas que ejercen la mendicidad y la prostitución, personas sin hogar y menores ${ }^{98}$.

Esta Ordenanza quiere realizar un esfuerzo de marcado carácter pedagógico en torno a la convivencia y la calidad de

97 Exposición de motivos de la Ordenanza de Convivencia Ciudadana de la Ciudad de Madrid.

98 Véase la Exposición de motivos, párrafo 10, de la Ordenanza de Convivencia Ciudadana de la Ciudad de Madrid. 
vida en la ciudad, intentando exponer las razones que justifican las actuaciones no permitidas y poniendo de relieve los beneficios que suponen para la comunidad. En este sentido, contempla la reparación del daño causado, así como la posibilidad de sustituir las sanciones económicas por prestaciones de carácter social.

Teniendo en cuenta el ámbito de aplicación, que se desarrolla en su artículo 4 y la finalidad perseguida por esta normativa, solo cabe añadir, que el objeto que tiene la Ordenanza es la prevención de cualquier tipo de actuación perturbadora de la convivencia ciudadana, la protección frente a las agresiones, alteraciones o usos indebidos, tanto de los bienes de servicio o uso público de titularidad municipal como de las instalaciones y elementos que forman parte del patrimonio urbanístico y arquitectónico del municipio de Madrid, la sanción de las conductas incívicas y la reparación de los daños causados ${ }^{99}$.

El Título II de dicha Ordenanza recoge todas aquellas actuaciones no permitidas en el espacio público. Las conductas reguladas en el capítulo I, encuentran su fundamento en la necesidad de evitar en el espacio público todas las prácticas individuales o colectivas que atenten contra la dignidad de las personas, salvaguardar el derecho que tienen los ciudadanos a transitar por el municipio de Madrid sin ser molestados o perturbados en su voluntad, la libre circulación de las personas, la protección de menores, así como el correcto uso del espacio público ${ }^{100}$. Por su parte en el capítulo II, se recogen todas aquellas conductas que impliquen un mal uso o un uso inadecuado del espacio público y con ello se pretende compatibilizar el derecho que todas las personas tienen a no ser perturbadas y a disfrutar lúdicamente del espacio público conforme a la naturaleza y al destino de éstos, con la obligación de mantenerlos en condiciones adecuadas de

99 Artículo 1.2 de la Ordenanza de Convivencia Ciudadana de la Ciudad de Madrid.

100 Art. 8: Fundamento de la regulación, de la Ordenanza de Convivencia Ciudadana de la Ciudad de Madrid. 
estética y limpieza ${ }^{101}$. Junto con estas conductas se regulan en el capítulo III, todas aquellas que supongan un uso inadecuado de los bienes y recursos públicos, con el fin de promover el uso racional del espacio público, el respeto a los bienes, la seguridad, la salud e integridad física de las personas y el patrimonio municipal ${ }^{102}$.

Con respecto al tema de la prostitución el artículo 11 de dicha Ordenanza regula la prohibición de aquellas conductas consistentes, en primer lugar, en la solicitud de servicios sexuales, prohibiendo en este sentido, solicitar, negociar o aceptar, directa o indirectamente, servicios sexuales. Sin que en ningún momento se haga alusión a aspectos más específicos de lo que conllevan estas actuaciones, más allá de que no se permite además, la solicitud de servicios sexuales en el espacio público cercano a centros docentes, zonas de juego infantiles y juveniles y accesos a centros comerciales y empresariales.

En segundo lugar, se prohíbe la práctica de servicios sexuales en el espacio público considerando que estas conductas, en cualquier caso, son incompatibles con los usos atribuidos al mismo.

Por último, se prohíben las conductas en el espacio público que puedan considerarse coactivas o de acoso a las personas, así como aquéllas que promuevan el consumo de prostitución u otras formas de explotación sexual, aunque en ningún caso se regulan expresamente cuáles son esas conductas.

En cuanto a los sujetos sobre los que recaen las sanciones y serán perseguidos en virtud de esta normativa, en ningún caso, en semejanza con las anteriores Ordenanzas Municipales, las personas en situación de prostitución serán sancionadas por las conductas referidas en el anterior artículo, únicamente se procederá a la sanción del cliente o el explotador ${ }^{103}$, si lo hubiere.

101 Artículo 13 de la Ordenanza de Convivencia Ciudadana de la Ciudad de Madrid.

102 Artículo 26 de la Ordenanza de Convivencia Ciudadana de la Ciudad de Madrid.

103 Véase al respecto el artículo 37.2 de la de la Ordenanza de Convivencia Ciudadana de la Ciudad de Madrid, "establece que las personas en situación de 
Según lo establecido en el artículo 39.3 de la Ordenanza la solicitud de servicios sexuales en el espacio público, es calificada como una infracción leve, mientras que aquella solicitud de servicios sexuales que pueda considerarse coactiva o de acoso a la persona, las conductas que promuevan el consumo de prostitución u otras formas de explotación sexual, y la solicitud de servicios sexuales en el espacio público cercano a centros docentes, zonas de juego infantiles y juveniles y accesos a centros comerciales y empresariales, constituyen infracciones graves $^{104}$. Finalmente las conductas que promueven el consumo de prostitución u otras formas de explotación sexual en el espacio público cercano a centros docentes y zonas de juego infantiles y juveniles, así como, la práctica de servicios sexuales en el espacio público, constituyen infracciones muy graves ${ }^{105}$.

Por su parte las infracciones leves serán sancionadas con una multa de hasta $750 €$, mientras que a las infracciones graves les corresponde una sanción económica de 750,01€ hasta 1.500 $€, \mathrm{y}$ a las infracciones muy graves multas desde $1.500,01 €$ hasta $3.000 €^{106}$. De cualquier modo el Ayuntamiento podrá autorizar que la sanción económica por la comisión de infracciones leves previstas en esta normativa pueda sustituirse por la prestación de servicios en beneficio de la comunidad. Este servicio personal sin sujeción laboral alguna y sin retribución, en actividades de utilidad pública, con interés social y valor educativo se plantea con el fin de concienciar sobre la gravedad de los hechos y ser evitados así en el futuro (artículo 44).

prostitución, en ningún caso serán sancionadas por las conductas que según este texto están prohibidas en relación con el ejercicio de la prostitución en el espacio público. Por lo tanto, se deduce de esta afirmación, que toda sanción impuesta por la comisión de alguna infracción, recaerá sobre clientes o proxenetas".

104 Artículos 40.5, 40.6 y 40.7 de la Ordenanza de Convivencia Ciudadana de la Ciudad de Madrid.

105 Artículos 41.4 y 41.5 la de la Ordenanza de Convivencia Ciudadana de la Ciudad de Madrid.

106 Artículo 42 la de la Ordenanza de Convivencia Ciudadana de la Ciudad de Madrid. 
No obstante, en el caso de infracciones en materia de servicios sexuales, puede llevarse a cabo una medida cautelar, en este caso, los agentes de autoridad informarán previamente de que esas prácticas no están permitidas por esta Ordenanza. Si la persona persistiera en su actitud y no abandonará el lugar, se establece que podrá ser sancionada por desobediencia a la autoridad ${ }^{107}$.

Finalmente, cuando hablamos de medidas de carácter social, la Ordenanza pone de manifiesto la actuación llevada a cabo por el Ayuntamiento, el cual dará prioridad a todas las medidas municipales encaminadas a prevenir riesgos para la convivencia ciudadana y el civismo en el espacio público ${ }^{108}$. En este sentido, se han desplegado multitud de medidas, con intervenciones en cada sector, como pudiera ser las personas afectadas por la mendicidad, o personas sin hogar, entre otros. A esta lista de sectores de la sociedad añadimos las intervenciones de carácter social dirigidas a personas en situación de prostitución ${ }^{109}$. Según esto, el Ayuntamiento, dentro del ámbito de sus competencias y en el marco de sus planes y programas vigentes, coordinará las actuaciones de atención social dirigidas a las personas que se encuentren en situación de prostitución en el municipio de Madrid. Será necesaria una colaboración por parte de las demás administraciones en los delitos de trata, proxenetismo o cualquier otra forma de explotación sexual, especialmente, en lo relativo a menores. A efectos de erradicar la prostitución del espacio público, las autoridades competentes, atenderán e informarán de los centros de atención social a los que se podrá acudir para recibir el apoyo que sea necesario.

Esta normativa no es el único instrumento del que dispone el Ayuntamiento de Madrid para luchar contra la prostitución y otras formas de explotación sexual. Junto al texto de la

107 Véase al respecto el artículo 47.1. Medidas cautelares, de la Ordenanza de Convivencia Ciudadana de la Ciudad de Madrid.

108 Artículo 32. Principio de prevención, de la Ordenanza de Convivencia Ciudadana de la Ciudad de Madrid.

109 Artículo 35 de la Ordenanza de Convivencia Ciudadana de la Ciudad de Madrid. 
Ordenanza Municipal que hemos analizado detenidamente, ya en el año 2004 el Ayuntamiento de Madrid puso en marcha el $I$ Plan Contra la Explotación Sexual y la atención a la prostitución en la ciudad de Madrid, iniciativa pionera en nuestro país con dos objetivos básicos: erradicar la demanda de prostitución en la ciudad de Madrid y prestar atención integral a las mujeres que la ejercen ofreciéndoles recursos y alternativas viables para el abandono de la prostitución. Para la consecución de ambos objetivos se han realizado diversas campañas de sensibilización, dirigidas tanto a demandantes de servicios sexuales, como a la sociedad en general, tendentes a visibilizar la situación de explotación y desigualdad que supone el intercambio de dinero por sexo, así como a conseguir una censura social generalizada que estigmatice a quien demanda servicios sexuales en lugar de a la mujer que sufre explotación sexual ${ }^{110}$.

Para el desarrollo del Programa de Atención Integral se crearon los primeros dispositivos municipales de atención: una Unidad Móvil para facilitar el acercamiento a las mujeres en los diversos escenarios en que se ejerce la prostitución y el Centro Concepción Arenal, dispositivo de atención específica y especializada a mujeres en situación de prostitución que realiza la valoración, diseño y seguimiento de los procesos individualizados de atención, recuperación e inserción socio-laboral de las mujeres que desean abandonar la prostitución.

Este primer plan estaba previsto para una vigencia desde el año 2004 hasta el año 2011. Partiendo de la experiencia durante la vigencia de este primer plan, por parte del Ayuntamiento se estima imprescindible continuar con la línea iniciada en el año 2004 de facilitar apoyo, asesoramiento, acompañamiento, formación y ayuda a las mujeres que lo requieran, dado que considera que todavía persisten situaciones y obstáculos que afectan a la igualdad de las mujeres y, de manera especial, a aquellas que se encuentran en una situación de vulnerabilidad, desventa-

110 Confróntense al respecto, GONZALEZ DEL RÍO, El ejercicio de la prostitución y el derecho del trabajo, 2013, p. 66. 
ja, desprotección o exclusión social. El II Plan, con una vigencia prevista hasta el año 2016, pretende además contribuir a la mejora de la convivencia ciudadana. Madrid es una ciudad abierta y cosmopolita, ello significa tener en cuenta, valorar y respetar a las personas, mujeres y hombres individuales así como conjugar y armonizar los distintos intereses, realidades y objetivos del conjunto de la ciudadanía ${ }^{111}$.

El plan se estructura en cuatro áreas, el área primera del nuevo Plan se dedica, al estudio y la investigación de la realidad de la prostitución en la ciudad de Madrid. Tal y como argumenta dicho plan, cualquier intervención requiere un conocimiento previo de la realidad sobre la que se pretende intervenir, especialmente en un ámbito tan heterogéneo y cambiante como es el de la prostitución ${ }^{112}$ y de manera especial en el caso de la prostitución masculina, menos conocida que la femenina y con implicaciones claras en el ámbito de la salud por la gran importancia de las infecciones de transmisión sexual y del virus de la inmunodeficiencia humana (VIH) entre los hombres que ejercen prostitución. Con respecto al segundo área que conforma el plan, se centra en la prevención y sensibilización de la sociedad sobre el fenómeno de la prostitución. Dentro de esta área merece especial atención la figura del demandante de prostitución femenina. Según el plan, los demandantes de prostitución, al demandar los servicios de una mujer en situación de prostitución, establecen una situación de dominio sobre su cuerpo al que consideran susceptible de compra-venta. Por ello, proponer acciones hacia los potenciales demandantes es dirigir líneas de actuación hacia toda la sociedad con el fin de que se construya una censura social explícita hacia el consumo de prostitución, es decir, uno de los objetivos perseguidos es desalentar la demanda de prostitución

111 Véase al respecto, ÁREA DE GOBIERNO DE FAMILIA Y SERVICIOS SOCIALES, II Plan contra la explotación sexual y la atención a la prostitución en la Ciudad de Madrid, Dirección General de Igualdad de Oportunidades, pp. 5-12.

112 En este mismo sentido, KAPPLER, K., en VILLACAMPA ESTIARTE, Prostitución: ¿hacia la legalización?, 2012, p. 2. 
en la ciudad de Madrid, y otro de los objetivos englobados en esta área, es conseguir que Madrid no sea un destino fácil para las redes y mafias de tratantes de seres humanos y proxenetas. A su vez, añade que, el desarrollo óptimo de estos objetivos dependerá de la formación de los profesionales, es por ello que se fomentará por parte del Ayuntamiento dicha formación.

Además de las posibles acciones dirigidas directamente hacia los demandantes de los servicios de prostitución, esta área recoge también acciones de sensibilización social destinadas a la población general, y específicamente, a educar en valores de igualdad y equidad a las generaciones más jóvenes.

Este segundo plan incorpora una nueva área de intervención respecto al plan anterior, el área tercera de Cooperación, según la cual será necesario llevar a cabo un intercambio de buenas prácticas, compartir estrategias y experiencias que analicen el impacto de las diversas iniciativas puestas en práctica en los últimos tiempos, tanto en el ámbito nacional como internacional, así como fomentar el establecimiento de redes de colaboración con las ciudades y países de origen de las personas que ejercen prostitución en la ciudad, al objeto de informar y formar, en origen, a las posibles víctimas de las redes y mafias de trata y articular mecanismos de prevención y vigilancia que permitan desarticular dichas redes, ya sea en origen, ya en destino. Todo ello cumpliendo objetivos como compatibilizar los diferentes intereses y derechos de las personas en el uso y disfrute del espacio público; promover la coordinación con los países de origen de las personas que ejercen prostitución en Madrid; y mejorar la calidad de la protección y el apoyo a las personas que ejercen prostitución.

Finalmente, el área cuarta está dedicada a consolidar los dispositivos de atención integral a mujeres en situación de prostitución y a poner en marcha nuevos recursos que permitan abordar la realidad de la prostitución masculina en la ciudad de Madrid, con especial atención a la prevención de infecciones de transmisión sexual y del virus de inmunodeficiencia humana, 
facilitando un diagnóstico precoz mediante la oferta de prueba rápida de VIH y facilitando el acceso a centros de tratamiento de Infecciones de Transmisión Sexual (ITS), con el fin de que la población destinataria del Programa tome conciencia de las estrategias preventivas y tenga acceso a las pruebas necesarias para un diagnóstico temprano, así como el tratamiento adecuado ${ }^{113}$.

\section{Críticas a las ordenanzas municipales}

España no ha mantenido tradicionalmente una política clara en materia de prostitución. Se trata de una actividad cuyo ejercicio no está regulado, pero que tampoco ha sido prohibido, salvo cuando implica a menores de edad o a adultos que la ejerzan de manera forzada. Sin embargo, en los últimos años se está produciendo un claro avance hacia la criminalización de las conductas relacionadas con la prostitución voluntaria. Este vacío legal a nivel estatal, ha desembocado en la aparición de una política municipal. Como hemos visto, muchos ayuntamientos de ciudades españolas, han aprobado ordenanzas municipales con las que se prohíbe el ejercicio del trabajo sexual en las calles, multando tanto a trabajadores sexuales como a clientes.

Algunas de las ordenanzas sólo sancionan la conducta de los clientes, esto es, se basan en el modelo sueco de la prohibición de compra de servicios sexuales, adoptando un abordaje claramente abolicionista, como en el caso de Sevilla o Valencia. Sin embargo, una parte de ellas, como las ordenanzas de Barcelona, Murcia o Granada, sancionan también a quienes ejercen la prostitución, siguiendo el modelo prohibicionista. Puede así indicarse que, por medio de estas ordenanzas municipales, España está adoptando un sistema que podría calificarse, tal y como afirma Villacampa, de pseudo-prohibicionista o prohibicionismo

$113 \mathrm{Al}$ respecto véase, ÁREA DE GOBIERNO DE FAMILIA Y SERVICIOS SOCIALES, II Plan contra la explotación sexual y la atención a la prostitución en la Ciudad de Madrid, Dirección General de Igualdad de Oportunidades, pp. 24-37. 
suave, pues sanciona a éstas, si bien con una sanción administrativa en lugar de con una sanción de carácter penal ${ }^{114}$, como se hace en Norteamérica. En cualquier caso no cabe duda de que todas ellas tienen su origen en la consideración de la prostitución como un problema de "convivencia ciudadana" y que, en consecuencia, se encaminan a la protección de la tranquilidad y la seguridad de los vecinos, más allá de que se prevea también la protección de otros bienes jurídicos como la salud pública.

En Barcelona, pionera en la aprobación de las ordenanzas cívicas, se observa como la reforma del año 2012, tenía por finalidad endurecer las sanciones económicas imponibles tanto a trabajadoras sexuales como a clientes y eliminar la necesidad de preaviso para imponer sanción. De la misma manera la cosa continúa, con el claro ejemplo de Cataluña, cuya prohibición no solo ha alcanzado el ejercicio de la prostitución en las vías públicas urbanas, sino también en las carreteras. La aplicación de la Ley va acompañada de la creación de un fichero con datos personales de trabajadores sexuales y de sus clientes, que es administrado por el Servicio Catalán de Tránsito y que permite poder tramitar las correspondientes sanciones ${ }^{115}$.

Ahora bien, el desarrollo y puesta en marcha de estas ordenanzas municipales, que se analizan, ha supuesto el despliegue de múltiples críticas por parte de varios sectores, desde académicos, organizaciones y colectivos que trabajan con este sector social, hasta los propios trabajadores del sexo han mostrado su disconformidad con la puesta en marcha de este tipo de políticas de cortes prohibicionista y abolicionista.

En este sentido crítico, según ponen de manifiesto autoras como Villacampa y Torres, la implementación de las llamadas ordenanzas cívicas municipales contra la prostitución son fundamentalmente una herramienta que hace más precarias aún las condiciones del ejercicio de la actividad de los trabajadores y trabajadoras sexuales y que por lo tanto, los victimiza, lejos

114 En este sentido, VILLACAMPA/TORRES, RECPC, 2013, pp. 5-6.

115 Al respecto véase, VILLACAMPA ESTIARTE/TORRES, RECPC, 2013, p. 6. 
de abolir, como supuestamente se pretende, el ejercicio de esta actividad $^{116}$. Ponen de manifiesto que las ordenanzas municipales contra la prostitución, e incluso otras normas en este sentido solo contribuyen a penalizar y criminalizar la pobreza.

Por otro lado afirman que la escasa efectividad de esta política se debe no solo al hecho de que no esté principalmente orientada a la erradicación de la misma, sino fundamentalmente a que su objetivo lo constituye sobre todo el barrido de los trabajadores sexuales de las calles y vías públicas. El único efecto claramente detectado con la aplicación de la ordenanza ha sido el represor ${ }^{117}$.

La tarea asistencial que se tendría que llevar a cabo con este colectivo, a pesar de que quede recogido en algunas ordenanzas, no se aplica casi nunca, añaden. De hecho el trabajo de estas autoras, remarca que los clientes han recibido menos sanciones pecuniarias que las personas que ejercen la prostitución. Aseguran que ni siquiera la ordenanza parece haber influido de manera determinante en la actitud de los clientes. Pero lo que sí que se ha probado, es un cambio de actitud de la policía municipal hacia las mujeres y de ellas hacia los agentes, que ahora los ven como controladores y no como protectores.

El estudio señala que las ordenanzas abocan a las prostitutas a un callejón sin salida, en la mayoría de los casos, tienen

116 Véase, VILLACAMPA/TORRES, RECPC, 2013, pp. 8-11. El objetivo principal de la investigación llevada a cabo por estas dos profesoras de Derecho penal, era conocer de qué manera afecta a las trabajadoras sexuales la aprobación de este tipo de normativa municipal tildada de "prohibicionista". Para lograr este objetivo se valieron del estudio de la ciudad de Lleida a modo de ejemplo. De igual modo pretendían conocer la opinión del sector del trabajo sexual sobre la eventualidad de que este trabajo sea considerado como tal, es decir, como una actividad laboral reconocida. En el mismo sentido véase, MAQUEDA ABREU, Olvido, p. 1-2.

117 Confróntense al respecto, ARELLA/FERNÁNDEZ BESSA/NICOLÁS/VARTABEDIAN, Una aproximación a la vulneración de los derechos humanos de las trabajadoras sexuales en la ciudad de Barcelona, Universidad de Barcelona/Observatori del Sistema Penal i elsDretsHumans, 2006, pp. 40 y ss.; VARTABEDIAN, en Quaderns-e InstitutCatalàd'Antropologia, 2013, p. 80. 
que continuar trabajando para poder pagar las sanciones, más allá de la voluntad de querer cambiar de actividad.

En definitiva a la conclusión, a la que han llegado Villacampa y Torres y que personalmente comparto, es que, "la política emprendida en nuestro país se encuentra muy lejos de conducir a la situación ansiada por las trabajadoras sexuales, máxime en un momento en que parece que la ofensiva contra el trabajo sexual callejero se está intensificando, traspasando las fronteras del Derecho administrativo sancionador municipal. Sin embargo, atendiendo a la escasa operatividad que está teniendo nuestra actual política "prohibicionista suave" en la mejora de las condiciones vitales de este colectivo, quizá el ensayo de políticas de corte legalizador sería más operativo. Con ellas, afirman que probablemente no se conseguiría el confesado objetivo de erradicar el ejercicio del trabajo sexual, pero al menos sí se dignificarían las condiciones de quienes prestan servicios remunerados de manera voluntaria en este ámbito" 118 .

Estas no han sido las únicas críticas que ha sufrido el despliegue de ordenanzas municipales, también han sido incesantemente contestadas por colectivos de trabajadores del sexo y de ONGs que realizan tareas asistenciales con éstos, en definitiva, por parte de los colectivos que defienden y protegen a este sector. Ellos también ven en esta normativa una forma de criminalizar la pobreza, que precariza todavía más las condiciones de trabajo de las prostitutas callejeras, que son cinco veces más multadas que los clientes ${ }^{119}$.

Afirman que sancionar a quienes ofrecen sexo en la calle no sirve para terminar con la prostitución. Solo contribuye a ocultarla en pisos y burdeles. La polémica medida no aborda, además, el problema de fondo, que es que no hay una postura común que apueste por regular o, por el contrario, abolir esta práctica ${ }^{120}$.

118 Véase, VILLACAMPA ESTIARTE/TORRES, RECPC, 2013, p. 37.

$119 \mathrm{Al}$ respecto véase, VILLACAMPA ESTIARTE/TORRES, RECPC, 2013, p. 40.

$120 \mathrm{Al}$ respecto confróntese, CARRANCO/SAHUQUILLO, "La prostitución, mejor debajo de la alfombra", El País, 2012. (Consultar http://sociedad. 
Por su parte la presidenta de la "Asociación para la Prevención, Reinserción y Atención de la Mujer Prostituida" (APRAMP) ${ }^{121}$, Rocío Nieto, también ha puesto de manifiesto la opinión que le merecen estas normas municipales y asegura que las chicas siguen vendiéndose en las calles, algo que molesta a muchos ciudadanos, que no quieren que sus hijos vean a mujeres con poca ropa que ofrecen su cuerpo por dinero. Por eso muchos municipios se han visto presionados para desarrollar estas Ordenanzas. Nieto afirma que "se está bordeando el problema y que lo que hay que hacer es una ley seria contra las personas que explotan a las mujeres"122. Apunta, además, que una persona a la que se le persigue y se está penalizando difícilmente va a acabar admitiendo que está siendo explotada.

A estas opiniones en contra se unen otras muchas, como la de María Luisa Balaguer, Catedrática de Derecho constitucional en la Universidad de Málaga, ésta explica que con estas normativas "se da un rodeo al problema y se utiliza una argucia legislativa para que no haya chicas en las calles". Sostiene, además, que esas multas son recurribles porque están en terrenos límite, "se podría esgrimir la inconstitucionalidad, por ejemplo, del derecho de libre de ambulación de las mujeres a las que multan por estar en una carretera". A su entender, los partidos políticos deberían abordar el problema, pero no es una cuestión de fácil consenso ${ }^{123}$.

elpais.com/sociedad/2012/05/31/vidayartes/1338491745 774783.html; última visita el 11 de enero de 2018).

121 Véase, APRAMP. (Consultar https://apramp.org/; última visita el 11 de enero de 2018).

$122 \mathrm{Su}$ asociación y muchas otras consideran que la mayoría de las mujeres que se prostituyen no lo hacen voluntariamente, sino que son víctimas de las mafias. Un argumento compartido también por las administraciones, que sin embargo no se pueden apoyar en cifras ni datos oficiales. Véase, CARRANCO/SAHUQUILLO, "La prostitución, mejor debajo de la alfombra", El País, 2012. (Consultar http://sociedad.elpais.com/sociedad/2012/05/31/ vidayartes/1338491745_774783.html; última visita el 11 de enero de 2018).

123 Véase, CARRANCO/SAHUQUILLO, "La prostitución, mejor debajo de la alfombra”, El País, 2012. (Consultar http://sociedad.elpais.com/socie- 
Hasta los propios Ayuntamientos han llegado a reconocer que con esta política municipal se valen de parches o apaños transitorios, a la espera de una norma estatal. El Ayuntamiento de la Jonquera, en Gerona, fue de los primeros en poner en marcha este sistema de multas, no obstante, un año después dejó de multar a los clientes y a las chicas porque no resultaba efectivo ni eficaz. El municipio tomó esta iniciativa dada la presión de los vecinos.

Por su parte, una de las mayores defensoras de los derechos de las trabajadoras del sexo y miembro de la Organización Hetaira, Cristina Garaizábal, entiende que multar a quienes ejercen la prostitución, sin ser esta actividad un delito propiamente dicho, "raya la inconstitucional"124. Garaizábal considera que las multas comportan otro problema añadido, y es que "se echa a las mujeres en manos de los clubes para que ahí sean víctimas de abusos, ya que no hay ninguna ley que reconozca relación laborar"125.

dad/2012/05/31/vidayartes/1338491745 774783.html; última visita: 11 de enero de 2018).

124 Según, GARAIZÁBAL, a su entender, "no todas las personas que se colocan en una carretera a vender su cuerpo lo hacen explotadas. Por eso, piden lugares específicos en los que puedan ejercer la prostitución con garantías de seguridad", Mugak, segundo trimestre de 2003.

125 En la misma línea, GARCÍA, "las consecuencias de la aplicación de estas ordenanzas son la persecución y acoso de las trabajadoras del sexo, empeoramiento de las condiciones de trabajo de estas mujeres, condiciones que ya eran bastante precarias y creación de un clima de inseguridad e indefensión que aumenta la vulnerabilidad de las trabajadoras y la posibilidad de agresiones. También pensamos que estas políticas favorecen el desarrollo de mafias y chulos dado que las trabajadoras del sexo, para evitar el acoso policial, se ven obligadas a buscarse "protectores" que les avisen de las redadas o las defiendan en el reparto del espacio, que suele ser muy escaso y estar muy contaminado por la marginación y la delincuencia. Y para más inri, estas normas están originadas por una administración pública, que debería ser el garante del estado de bienestar y quien tendría el deber de preservar los derechos de todos y todas, también los de las minorías", Ordenanzas municipales y prostitución. El caso de Gandía, COLECTIVO HETAIRA, 2010. (Consultar http://www.colectivohetaira.org/web/enmedios-de-comunicacion/15-articulos-de-prensa-propios/239-ordenanzasmunicipales-y-prostitucion-el-caso-de-gandia.html, última visita el 16 de febrero de 2018). 
Viviana Waisman, directora de "Women'sLinkWorldwide"126, sostiene que las ordenanzas ciudadanas violan, además, varios tratados internacionales de prevención y lucha contra el tráfico de seres humanos. "Castigar a las mujeres que ejercen la prostitución tiene el peligro de colocarlas en una situación de mayor vulnerabilidad, lo que contraviene todos los instrumentos internacionales de protección a las víctimas de trata. Debe primar la persona y las violaciones a sus derechos humanos. Es esencial que este sea el marco, y no uno que se centre en la persecución del delito ni en el control migratorio", afirma.

Por su parte, Purificación Causapié, ex secretaria de Igualdad del PSOE, también mostró su desacuerdo con las normas municipales que penalizan a las personas que ejercen la prostitución. "Estas ordenanzas tienen más que ver con el vandalismo y el orden público. Hay que combatir el tráfico de personas y las mafias y facilitar que las mujeres salgan de esta situación con ayudas", considera. Comprende la postura de los Ayuntamientos, pero cree que la manera de erradicar la prostitución es combatir el tráfico y la explotación. "Penalizar a las mujeres solo las estigmatiza, esconde y dificulta su seguimiento", argumenta Causapié, más partidaria de multar solo al cliente, como se hace en Sevilla o en Valencia.

Estas han sido algunas de las muchas opiniones o críticas que han suscitado las Ordenanzas Municipales en vigor en algunas de nuestras ciudades. Me sumo a éstas opiniones entendiendo que imponer multas a las prostitutas y/o a sus clientes, no es una medida correcta para erradicar la trata, ni la propia prostitución, como se pretende justificar, sino que se trata de una medida represiva, enmascarada en una política criminal de hipocresía, que lo único que consigue es aumentar la victimización de los que ejercen la prostitución y ralentizar la lucha por sus derechos ${ }^{127}$.

126 Es una organización reconocida por su capacidad de desarrollar teorías y estrategias legales, en especial respecto a violaciones de derechos humanos de las mujeres.

127 Argumento desarrollado por GRETA en su informe, Reportconcerningtheimplementationofthe Council ofEuropeConventiononActionagainst- 


\section{Conclusiones}

Como hemos visto hasta el momento la política desplegada en España, en materia de prostitución, ha sido muy insuficiente, limitada al ámbito administrativo, a través de las múltiples ordenanzas municipales, que cada ayuntamiento ha creado y desarrollado en su territorio. Por supuesto, como ya sabemos, esta regulación de sanciones administrativas, que pretenden velar por el cumplimiento de un correcto uso de los espacios públicos, en condiciones de civismo y convivencia, únicamente es de aplicación para esta finalidad, y por consiguiente en ningún momento se trata de una regulación de la prostitución de forma autónoma. La única vía legislativa del Estado Español, en esta materia, la encontramos en nuestro Código penal, que regula so pena de prisión, las conductas de prostitución coactiva, es decir, las figuras del proxenetismo o explotación sexual de un tercero, la trata de personas con fines de explotación sexual, o incluso el aprovechamiento o lucro de la explotación de la prostitución ajena, aún con el consentimiento del sujeto prostituido. En definitiva, nada se dice en nuestra regulación penal, de aquellas conductas que consisten en ejercer la prostitución libre y voluntariamente sin que medie la intervención de un tercero, y por tanto, no se trata de una conducta delictiva.

Hasta marzo de 2015, este era el panorama que podíamos encontrarnos en nuestro país, con respecto al tema de la prostitución. Sanciones administrativas municipales, frente al vacío legal a nivel estatal. Pues bien, tras esta fecha que hemos apuntado, se ha dado un pequeño giro al "escenario prostitucional" a partir de que se aprobó la Ley Orgánica 4/2015 de Seguridad Ciudadana ${ }^{128}$, que si bien ha dado cobertura estatal a este asunto, lo hace desde la perspectiva administrativa, es decir, nada parece

Trafficking in Human BeingsbySpain, (Informe sobre la implementación por parte de España del Convenio del Consejo de Europa sobre la lucha contra la trata de seres humanos), 2013. (Consultar http://www.colectivohetaira. org/web/images/docs/greta2013.pdf, última visita el 21 de agosto de 2017).

128 Ley Orgánica 4/2015 de 30 de marzo, de protección de la seguridad ciudadana. 
cambiar en cuanto al régimen penal, sino que se mantiene el régimen sancionador de multas administrativas, aunque ampliando el ámbito de aplicación del nivel local al estatal.

Igual que ocurre con las distintas ordenanzas municipales, que los distintos ayuntamientos han establecido en sus territorios, para perseguir el ejercicio de la prostitución en las calles de sus ciudades, las críticas a esta Ley de Protección de la Seguridad Ciudadana no se han hecho esperar, esta Ley aprobada únicamente por los votos del Partido Popular, durante su periodo de gobernanza, 2011-2015, ha levantado numerosas ampollas entre distintos sectores de la sociedad, incluida la oposición política y el resto de partidos.

Con respecto a los trabajadores sexuales, como uno de los sectores mayormente afectados por el despliegue y puesta en marcha de este texto, que como ya sabemos, ve aumentada la represión sobre ellos, no solo por la legislación autonómica o local, sino que a estas prohibiciones se une la prohibición marcada por la Ley de Seguridad Ciudadana. Este sector, ha visto como desde la entrada en vigor de la ley el efecto sancionador ha crecido, bien recayendo sobre el cliente, tal y como se prevé en la ley, por la solicitud o demanda de servicios sexuales, bien recayendo sobre el trabajador sexual, justificando la sanción en base a la desobediencia a la autoridad en la que éste pudiese incurrir por la negativa a desistir en sus prácticas, ante el requerimiento policial.

Esta ausencia de regulación estatal con respecto a una clara tendencia abolicionista o legalizadora de la actividad de la prostitución en un ámbito de libertad y voluntariedad y que ha desembocado en una politización autonómica y local al respecto, a través de diversas Ordenanzas Municipales, ha permitido que cada ayuntamiento establezca las condiciones para ejercer esta actividad y las posibles sanciones administrativas que van aparejadas al incumplimiento de algunas de esas condiciones. Sin perjuicio, claro está, de la regulación penal estatal a la que ya apuntábamos. 
Aunque no exista un sistema claramente definido en nuestro país, las políticas autonómicas, han optado, en el algunos casos, por un evidente prohibicionismo, puesto que en aras a una supuesta preservación del espacio público como ámbito de convivencia y civismo, con el objeto de evitar las conductas que puedan perturbar la convivencia, evitar la visión de trabajadores sexuales a los menores o para evitar el entorpecimiento del tráfico vial, se prohíbe tanto el ofrecimiento, cuanto la solicitud, la negociación y la aceptación de servicios sexuales en la vía pública, lo mismo que la práctica de relaciones sexuales en el espacio público ${ }^{129}$. Por otro lado, hemos podido ver, como en algunos casos, esa prohibición no se traduce en sanciones para quien ejerce la prostitución, sino para el cliente, respondiendo así a grandes rasgos, a un claro ejemplo de modelo abolicionista.

Esta alegalidad se caracteriza porque no existe intervención estatal en la práctica de la prostitución, solo se actúa ante el proxenetismo, exigiéndose en este tipo delictivo coacción física o psicológica, y quedando por tanto fuera del delito de explotación, la prostitución voluntariamente ejercida por mayores de edad $^{130}$.

El resultado de este vacío legal es que las personas que ejercen la prostitución actúan al margen del sistema y no tienen ninguna protección jurídica lo que provoca que se conviertan en víctimas de los proxenetas ${ }^{131}$.

Así, por ejemplo, siguiendo el modelo de sociedad barcelonesa, la Ordenanza aprobada por el Ayuntamiento de Barcelona pretende ser una herramienta efectiva para hacer frente a las situaciones y circunstancias que puedan afectar a la convivencia

129 Véanse al respecto, VILLACAMPA ESTIARTE, REPC, 2015, pp. 413-455; GAY HERRERO, en SERRA CRISTOBAL (coord.), Prostitución y trata: marco jurídico y régimen de derechos, 2007, pp. 124-126.

$130 \mathrm{Al}$ respecto véase, POYATOS I MATAS, La prostitución como trabajo autónomo, 2009, p.22.

131 Confróntense al respecto, CARMONA CUENCA, en SERRA CRISTOBAL (coord.), Prostitución y trata: marco jurídico y régimen de derechos, 2007, p. 51; CUERDA ARNAU, en VV.AA, Delitos contra la libertad sexual, Consejo General del Poder Judicial, 1997. 
o alterarla y que, al igual que en cualquier otra gran ciudad europea, se producen en Barcelona, en un mundo cada vez más globalizado. Intenta ser una respuesta democrática y equilibrada a esas situaciones y circunstancias, basándose, por un lado, en el reconocimiento del derecho de todos a comportarse libremente en los espacios públicos y a ser respetados en su libertad; pero, por otro lado, también, en la necesidad de que todos asuman determinados deberes de convivencia y de respeto a la libertad, la dignidad y los derechos reconocidos a los demás, así como al mantenimiento del espacio público en condiciones adecuadas ${ }^{132}$.

Según lo expuesto en este trabajo, podemos deducir que la política que ha seguido el Ayuntamiento de Barcelona para abordar el tema de la prostitución está inspirada en el claro objetivo de acabar con la prostitución que capta su clientela en las calles catalanas ${ }^{133}$. Como asegura Poyatos i Mata, "se producen dos prohibiciones absolutas, por un lado, el ejercicio de la prostitución a menos de doscientos metros de centros docentes, y por otro, mantener relaciones sexuales en espacios públicos". Añade que "se produce también una prohibición relativa o indeterminada que limita la negociación de servicios sexuales en espacios públicos en los usos públicos de tales espacios". Por ello, man-

132 Véase la exposición de motivos de la Ordenanza de medida para fomentar y garantizar la convivencia ciudadana en el espacio público de Barcelona, segundo párrafo. En sentido contrario, VARTABEDIAM, asegura que "la particularidad de esta norma es que, en realidad, no se dirige a todos los ciudadanos y ciudadanas en general sino que se centra específicamente en colectivos entendidos como "problemáticos y molestos". Por lo tanto, de manera manifiesta se incluye en esta normativa a "grupos determinados de personas como ejecutoras de conductas incívicas. Las trabajadoras sexuales forman parte de uno de los grupos criminalizados", Oñati Socio-legal Series, 2011, p. 8. En la misma línea, HEIM, D., Obstáculos y dificultades de la reubicación de trabajadoras sexuales en el mercado laboral, 2007, p. 25.

133 Confróntensen al respecto, ARELLA/FERNANDEZ/NICOLAS/VARTABEDIAN, Los pasos (in) visibles de la prostitución, 2007, p. 10; ARELLA/ FERNÁNDEZ BESSA/NICOLÁS/VARTABEDIAN, Una aproximación a la vulneración de los derechos humanos de las trabajadoras sexuales en la ciudad de Barcelona, Universidad de Barcelona/Observatori del Sistema Penal i els Drets Humans, 2006, pp. 27 y ss.; VILLACAMPA ESTIARTE/ TORRES, RECPC, 2013, p. 5. 
tiene que la abstracción de la norma ha permitido un margen de discrecionalidad a la Guardia urbana para decidir cuándo sancionar o no esta práctica ${ }^{134}$.

Similar a la ordenanza desarrollada por la ciudad de Barcelona, encontramos las ordenanzas de Murcia y Granada, que en busca de la erradicación de esta práctica en las calles de sus ciudades persiguen y sancionan a quienes ejercen la prostitución y a quienes solicitan sus servicios.

En el lado opuesto a estos modelos de ordenanzas de corte prohibicionista, encontramos la ordenanza aprobada por el Ayuntamiento de Sevilla, este entiende que la mujer en situación de prostitución ha de tener la consideración de víctima, ya que la prostitución es una forma extrema de violencia de género. $\mathrm{Y}$ es en este contexto donde hay que considerar como beneficiarios de la explotación sexual tanto al proxeneta como al cliente. Continúa manifestando que no se puede ni se debe dar el mismo tratamiento a la víctima y al explotador. Es por ello que esta normativa sanciona la demanda de servicios sexuales, favorecimiento, promoción o facilitación de estas conductas, y nunca el ofrecimiento por parte de la víctima, a diferencia de las otras ordenanzas. Pero ahora bien, a esta afirmación de que en ningún caso se sancionará a la persona prostituta, o lo que es lo mismo, la víctima, cabe añadir que resulta en cierto modo contradictoria con el hecho de que sea sancionado el mantener relaciones sexuales retribuidas en el espacio público, ya que es evidente que en la práctica de esas relaciones sexuales intervienen tanto el que presta el servicio como el cliente, por tanto si la intención es mantener fuera del régimen sancionador a quien ejerce la prostitución sería conveniente matizar quien es el sujeto que en el ámbito de esta conducta, debe responder de la misma.

134 Según, POYATOS I MATAS, “...El nuevo posicionamiento municipal prohibitivo de una actividad tolerada hasta el momento- y de imposible eliminación- ha servido de justificación para establecer un sistema de sanciones dulcificadas de amplio margen discrecional en su aplicación", La prostitución como trabajo autónomo, 2009, p. 36. Al respecto, STSJ Cataluña. Sala de lo Contencioso, 464/2007; STS, Sala Tercera, de lo Contenciosoadministrativo, Sección 6a, Sentencia de 22 Abr. 2010, rec. 506/2007. 
Lo mismo ocurre en las ordenanzas de los ayuntamientos de Valencia y Madrid. Además, en cuanto a la Ordenanza de Valencia, cabe reflexionar sobre algunos términos que podrían ser dados a la confusión, estamos hablando concretamente del término "ofrecer", en cuanto a conducta que queda prohibida a tenor de la ordenanza. Este término, en consonancia con los servicios sexuales, es evidente que hace referencia al sujeto activo que ofrece tales servicios, o lo que es lo mismo, la persona que ejerce la prostitución, por lo tanto el sujeto infractor en este caso sería el trabajador sexual, lo que resulta contradictorio con lo establecido en el artículo 3.2 que excluye del ámbito del régimen sancionador a las personas en situación de prostitución.

Han pasado más de cuarenta años desde que se aprobara en 1970 la abolida "Ley de Peligrosidad y Rehabilitación Social" ${ }^{135}$, y España es definida como un Estado democrático social y de derecho, pero podríamos decir que apenas ha cambiado nada $^{136}$. Con la puesta en marcha de estas ordenanzas, en un intento de ordenar el espacio público invadido por quienes ejercen la prostitución, se han sobrepasado sus competencias porque afectan a los derechos fundamentales, que han de ser regulados

135 En esta ley se recogía como uno de los fines, concretamente en el quinto, "establecer las nuevas categorías de estados de peligrosidad que las actuales circunstancias sociales demandan por ofrecerse ciertamente como reveladoras de futuras y probables actividades delictivas o de presentes y efectivas perturbaciones sociales con grave daño o riesgo para la comunidad. Tales como las referencias al ejercicio habitual de la prostitución (...)". Y en el artículo segundo se especificaba que serían declarados "en estado peligroso" y les serían aplicadas las correspondientes medidas de seguridad y rehabilitación a quienes (entre otros) "habitualmente ejerzan la prostitución".

136 En este sentido según, MIRÓ I ARDĖVOL, "durante el franquismo, la prostitución era tolerada como un mal casi -o sin el casi- necesario, y hoy lo es desde la permisividad, una evolución de grado pero dentro de la misma escala en el sistema de valores: se funciona desde el fatalismo o irreversibilidad del hecho y de este se pasa a su aceptación, criterio que si fuera aplicado a otras patologías sociales daría lugar a un marco legislativo bien diferente del actual", Consideraciones sobre la prostitución y su legalización. Reflexiones en relación al proyecto de regulación y limitación de servicios sexuales remunerados, del Dpto. de interior de la Generalitat de Cataluña, Universitat Abat Oliba CEU, 2006, p. 1. 
mediante normas con rango de ley. Sin ninguna duda, estas ordenanzas siguen criminalizando a los trabajadores sexuales que intentan captar a sus clientes en la calle. No se tienen en cuenta las circunstancias por las que éstas, están en la calle, pudiendo estar incluso en situación de trata. Además resulta incoherente intentar prevenir la explotación de determinados colectivos, cuando las multas se las ponen a quienes ejercen y no a los presuntos proxenetas o explotadores. Hay que añadir además que no han conseguido que desaparezca la prostitución de las calles, no hay suficientes efectivos policiales para controlar veinticuatro horas a todas las personas y el único efecto es que se produce un desplazamiento de este sector, a otras zonas o ciudades con menor represión. En definitiva, son un ejemplo de políticas ineficaces, no solo no se consiguen sus fines sino que las personas a las que van dirigidas terminan estando en situación de mayor vulnerabilidad. Así, por ejemplo, las trabajadoras del sexo no pueden negociar con tranquilidad, lo que hace que tengan que aceptar condiciones mucho más duras, como son tarifas más bajas, prácticas de riesgo..., para poder compensar la pérdida de ingresos. De igual modo, van acumulando el importe de las multas y no pueden hacer frente al pago.

Desde mi postura considero pues, que se ha optado por una clara criminalización de la prostitución. Si el objetivo de esta política, era acabar con este sector social y con esta práctica, es evidente que no se ha conseguido, sino que por el contrario, ha servido sobre todo para estigmatizar aún más a las trabajadoras sexuales más desfavorecidas, las que trabajan en la calle. Aunque permítanme que ponga en duda sus buenas intenciones, porque considero que no existe una clara intención de acabar con la prostitución sino más bien de invisibilizar a este sector, que puede resultar molesto e "incómodo", para el resto de ciudadanos. A lo que debemos añadir que no existen evidencias de que el número de trabajadoras sexuales haya disminuido, más bien de lo contrario, al menos atendiendo a la percepción de las mismas trabajadoras sexuales, que lamentan el incremento de la competencia. 
De todas estas cuestiones podemos extraer varias reflexiones.

En primer lugar, que se ha barrido a las trabajadoras sexuales del espacio público, invisibilizando su existencia, pero no se han atacado eficazmente las causas que pueden conducir a las personas al desempeño del trabajo sexual, puesto que las medidas emprendidas se han limitado a incidir en el entorno físico o ambiental, pero no han atacado las bases sociales del problema.

A mi entender esta situación en nada beneficia a los trabajadores sexuales, que están en manos de proxenetas y explotadores sin tener ningún tipo de protección social. Incluso en el mejor de los casos, en el que haya personas que ejercen libremente y de forma autónoma, esta alegalidad los mantiene igualmente desprotegidos y sin reconocimiento de derechos. Peor aún me parece que este vacío legal que impera en nuestro país, permita politizar a nivel autonómico y local, sobre asuntos que son de competencia estatal.

Por otro lado entiendo que se sanciona aquellas conductas que puedan resultar perjudicial para el mantenimiento de esa seguridad ciudadana, sin embargo parece que la ley se olvida de que las personas que ejercen la prostitución también son ciudadanos y por consiguiente también deben ser protegidos y también se debe velar por su seguridad, cosa que evidentemente ha quedado olvidada. No resulta muy productivo atender la prostitución como el problema real que es, personalmente creo que se pretende adoptar una actitud "políticamente correcta", a favor de una sociedad que únicamente quiere calles limpias de prostitución, donde no esté presente la delincuencia y las drogas que rodean al mundo de la prostitución, lo que sin duda me parece legítimo. Sin embargo, nadie politiza a favor de aquellas personas que ejercen su trabajo, y que están desprotegidas, estigmatizadas, carentes de derechos, en situaciones precarias de marginalidad y expuestas a continuos peligros. Se busca proteger y asegurar la paz y la tranquilidad del resto de ciudadanos 
olvidando la seguridad de ese otro sector que permanece en las sombras, en de las personas que ejercen la prostitución.

Y como afirma De Lucas, se han articulado medidas normativas de carácter preventivo, que tienden a apartar a quienes se consideran amenazas potenciales a la seguridad de los espacios públicos, partiendo de un concepto restrictivo de ciudadanía, fundamentalmente apegada a la nacionalidad, que segrega a quienes no se hallan integrados en dicho concepto y que excluye a los considerados indeseables. El espacio público deja así de ser para todos y pasa a ser patrimonio exclusivo de determinados ciudadanos, con lo que deja de ser realmente espacio público ${ }^{137}$.

\section{Bibliografía}

ABITS/ADPC, El tratamiento de la prostitución y la trata con fines de explotación sexual en los medios de comunicación. Recomendaciones, Ayuntamiento de Barcelona, 2006.

ÁREA DE GOBIERNO DE FAMILIA Y SERVICIOS SOCIALES, II Plan contra la explotación sexual y la atención a la prostitución en la Ciudad de Madrid, Dirección General de Igualdad de Oportunidades.

ARELLA, "Gestión del espacio público y derecho a la ciudad. El caso del trabajo sexual", en VALIÑO (coord.), Defender y repensar los derechos sociales en tiempo de crisis, Barcelona: Observatori DESC, 2009.

ARELLA/FERNÁNDEZ BESSA/NICOLAS/VARTABEDIAN, Los pasos (in) visibles de la prostitución. Estigma, persecución y vulneración de los derechos de las trabajadoras sexuales en Barcelona, Barcelona, 2007.

ARELLA/FERNÁNDEZ BESSA/NICOLAS/VARTABEDIAN, Una aproximación a la vulneración de los derechos humanos de las trabajadoras sexuales en la ciudad de Bar-

137 Véase al respecto, DE LUCAS, en CIERCO/GARCÍA/SILVEIRA (coords.), Uso y control del espacio público: viejos problemas, nuevos desafios, 2015, p. 53 . 
celona, Universidad de Barcelona/Observatori del Sistema Penal i els Drets Humans, 2006.

AYUNTAMIENTO DE BARCELONA, Programa para el Abordaje Integral del Trabajo Sexual y la Agencia, 2013. Disponible en https://w110.bcn.cat/portal/site/ServeisSocials/menuitem.7292db498a2803aaca63ca63a2ef8a 0c/index0d05.html?vgnextoid $=614 \mathrm{bf6367 \textrm {cb } 5 \mathrm { f } 3 1 0 \mathrm { VgnV }}$ CM1000001947900aRCRD\&vgnextfmt $=$ formatDetall\& vgnextchannel $=80445 \mathrm{ab} 6 \mathrm{eaebb} 210 \mathrm{VgnVCM} 10000074 \mathrm{f}$ ea8c0RCRD\&lang=es ES

AYUNTAMIENTO DE SEVILLA, Plan de acción integral para promover la erradicación de la trata, la prostitución y otras formas de explotación sexual. Informe de acciones desarrolladas en diciembre de 2011, 2011. Disponible en http://www.sevilla.org/ayuntamiento/competenciasareas/area-de-igualdad-juventud-y-relaciones-con-lacomunidad-universitaria/a-mujer/plan-integral-contrala-prostitucion/informe-de-evaluacion-diciembre-2011.

CARMONA CUENCA, “¿Es la prostitución una vulneración de derechos fundamentales?", en SERRA CRISTÓBAL (coord.), Prostitución y trata: marco jurídico y régimen de derechos, Valencia, ed. Tirant lo Blanch, 2007.

CARRANCO/SAHUQUILLO, "La prostitución, mejor debajo de la alfombra", El País, 2012. Disponible en http:// sociedad.elpais.com/sociedad/2012/05/31/vidayartes/1338491745 774783.html.

CARRETERO, "España ante la prostitución en el siglo XXI: de la tolerancia a la abolición", Biblioteca Digital de la UNED. Disponible en http://www.uned.es/ca-tortosa/Biblioteca_Digital/Biblio/Carmen_Carretero/Espana.pdf.

CARRETERO, "Notas sobre las historia social de la prostitución hasta el siglo XX. El caso de Tomelloso”, Revista de Estudios Superiores a Distancia Universidad Abierta, núm. 27, 2008.

CUERDA ARNAU, "Los delitos de exhibicionismo, provocación sexual y prostitución de menores", en AA.VV, Deli- 
tos contra la libertad sexual, Consejo General del Poder Judicial, Madrid, 1997.

DE LUCAS, "Espacio público y personas: más allá de la ciudadanía nacional", en CIERCO/GARCÍA/SILVEIRA (coords.), Uso y control del espacio público: viejos problemas, nuevos desafios, Thomson Reuters- Aranzadi, Cizur Menor, 2015.

GARAIZÁBAL, "Derechos laborales para las trabajadoras del sexo", Mugak, n 23, segundo trimestre de 2003.

GARCÍA ÁLVAREZ, "La nueva regulación de los delitos contra la libertad e indemnidad sexual tras la reforma operada en el Código penal por la LO 1/2015, de 30 de marzo", La reforma del Código penal a debate, Cuadernos Penales José María Lidón, núm. 12, 2016.

GARCÍA, Ordenanzas municipales y prostitución. El caso de Gandia, COLECTIVO HETAIRA, 2010. (Consultar http://www.colectivohetaira.org/web/en-medios-decomunicacion/15-articulos-de-prensa-propios/239-ordenanzas-municipales-y-prostitucion-el-caso-de-gandia.html

GAY HERRERO, "Fórmulas jurídicas reconocedoras de los derechos profesionales de las trabajadoras sexuales", en SERRA CRISTOBAL (coord.), Prostitución y trata: marco jurídico y régimen de derechos, Valencia, ed. Tirant lo Blanch, 2007.

GONZÁLEZ DEL RÍO, El ejercicio de la prostitución y el derecho del trabajo, Granada, ed. Comares, 2013.

GRACIA RETORTILLO, “Convivencia ciudadana, prostitución y potestad sancionadora municipal. El caso de Barcelona", Estudios QDL, Universidad de Barcelona, 2008.

GRETA, La implementación por parte de España del Convenio del Consejo de Europa sobre la lucha contra la trata, 2013. http://www.colectivohetaira.org/web/images/docs/ greta2013.pdf.

GUEREÑA, La prostitución en la España contemporánea, Madrid, ed. Marcial Pons, 2003.

HEIM, D., Obstáculos y dificultades de la reubicación de trabajadoras sexuales en el mercado laboral: informe de 
investigación. Primera parte: prostitución y exclusión social, Barcelona: Surt, 2007.

JIMÉNEZ ASENSIO, "Potestad normativa municipal y convivencia ciudadana", Fundación Democracia y Gobierno Local, 2005.

JIMÉNEZ BAUTISTA, "El análisis de la prostitución en la ciudad de Granada (España)", Red de Revistas Cientificas de América Latina y El Caribe, España y Portugal, vol. $11, \mathrm{n}^{\circ} 22,2008$.

KAPPLER, K. E., "Entre el dramatismo y el punto ciego: perspectivas sociológicas sobre la prostitución en España", en VILLACAMPA ESTIARTE (coord.), Prostitución: ¿hacia la legalización?, Valencia, 2012.

MAQUEDA ABREU, “¿Qué pasa con la prostitución de las mujeres? Algunas reflexiones desde un discurso de los derechos", Olvido. Disponible enhttp://www.olvidos.es/ app/webroot/pdf/maqueda.pdf

MAQUEDA ABREU, Prostitución, feminismo y derecho penal, Granada, 2009.

MARINA, Lucha por la dignidad, Ponencia del Congreso Internacional Derechos Humanos y Prostitución. Ayuntamiento de Madrid, 2006.

MARTIN TORPEDO, Prostitución organizada: género, raza, clase y globalización de la explotación, Madrid, 2006.

MERINO ESTRADA, "Las nuevas ordenanzas municipales reguladoras de la convivencia ciudadana", Revista de estudios de la administración local y autonómica, núm. 300-301, 2006. Disponible en file:///C:/Users/usuario/ Downloads/9306-9533-1-PB.pdf.

MIRÓ I ARDĖVOL, Consideraciones sobre la prostitución y su legalización. Reflexiones en relación al proyecto de regulación y limitación de servicios sexuales remunerados, del Dpto. de interior de la Generalitat de Cataluña, Universitat Abat Oliba CEU, Barcelona, 2006.

NAVALPOTRO BALLESTEROS, "Las opciones jurídicas al alcance del Ayuntamiento de Madrid para mitigar las mo- 
lestias a los vecinos y residentes derivadas del ejercicio de la prostitución, Ayuntamiento de Madrid", Anuario de Derecho Municipal, 2007.

PEMÁN GAVÍN, "Ordenanzas municipales y convivencia ciudadana: reflexiones a propósito de la Ordenanza de civismo de Barcelona", Revista de Estudios de la Administración Local y Autonómica, núm. 35, 2007.

PEMÄN, J., "La política de civismo en los ayuntamientos españoles. Entre policía, acción social y educación cívica", Revista Aragonesa de Administración Pública, núm. 36, 2010.

POYATOS I MATAS, La prostitución como trabajo autónomo, Barcelona, 2009.

QUINTERO OLIVARES, “Antinomias y contradicciones en la intervención penal en la prostitución libre", en VILLACAMPA ESTIARTE (coord.), Prostitución: ¿hacia la legalización?, Valencia, 2012.

VARTABEDIAN, "Tengo mucho placer para enseñarte: sobre travestis brasileñas trabajadoras del sexo y la gestión pública de la prostitución en Barcelona", Quaderns-e Institut Catalàd'Antropologia, vol. 18, núm. 1, 2013.

VARTABEDIAN, "Trabajo sexual en Barcelona. Sobre la gestión municipal del espacio público", en Oñati Socio-legal Series, vol. 1, núm. 2, 2011.

VERA FERNÁNDEZ-SANZ, "Ejercicio de la prostitución y licencias municipales: usos económico-mercantil, comercial y urbanístico de los locales abiertos al público", Actualidad Administrativa, núm. 18, 2006.

VILLACAMPA ESTIARTE, "A vueltas con la prostitución callejera: ¿hemos abandonado definitivamente el prohibicionismo suave?", REPC, vol. XXXV, 2015.

VILLACAMPA ESTIARTE, "Políticas de criminalización de la prostitución: análisis crítico de su fundamentación y resultados", RDPC, 2012.

VILLACAMPA ESTIARTE/TORRES, "Políticas criminalizadoras de la prostitución en España. Efectos sobre las tra- 
bajadoras sexuales", RECPC, núm. 15-16, 2013. Disponible en http://criminet.ugr.es/recpc/15/recpc15-06.pdf. WIJERS, M., "Delincuente, víctima, mal social o mujer trabajadora: perspectivas legales sobre prostitución", en OSBORNE (ed.),Trabajador@s del sexo: derechos,migraciones y tráfico en el S. XXI, Barcelona, 2004.

\section{Jurisprudencia}

STS, Sala Tercera, de lo Contencioso-administrativo, Sección $6^{a}$, Sentencia de 22 Abr. 2010, rec. 506/2007.

STSJ Cataluña. Sala de lo Contencioso, 474/2006.

STSJ Cataluña. Sala de lo Contencioso, 464/2007.

STSJ Cataluña. Sala de lo Contencioso, 83/2010. 